\title{
Comparative economic viability and environmental impact of PV, diesel and grid systems for large underground water pumping application ( 55 wells) in Jordan
}

\author{
Mahmoud Hammad ${ }^{1}$ and Munzer S. Y. Ebaid ${ }^{2 *}$
}

\begin{abstract}
The current work was based on four selected underground water production wells (W25, W29, W34 and W47), out of 55 wells available in total, at Disi water project located south of Jordan to power underground water pumping using a stand-alone solar photovoltaic (PV) system for an operation period of 25 years. The economic viability of large stand-alone solar PV system of $13 \mathrm{MW}$ in total had been analysed through life-cycle cost computation compared with other four possible powering options, i.e. genset-powered, grid-networked systems, PV-grid and PV-genset. Individual cost banks were identified and studied based on previous practical experiences. Results of the life cycle costs per kWh in the order from the best to worst alternative is the PV (US\$0.136 / kWh), PV/grid (0.140), grid (US\$0.144 / kWh), PV-genset (0.185), and genset (US\$0.239 / kWh), respectively. This proved that the PV solar system is more cost effective and suitable to use over other conventional types of energy for such large power system. Also, payback period analysis was carried out and showed that the PV system is a good option to be recommended highly compared with the other options. Following, the environmental aspects of using clean PV energy were discussed. The resulting savings in $\mathrm{CO}_{2}$ emission reached 30,000 tons per well throughout the study period, which summed up to about 1.5 million tons of $\mathrm{CO}_{2}$ for all Disi wells. A briefed risk assessment was conducted for the intended project. Risk levels associated to several hazards were identified as well. The work in this paper can be generalized to other cases worldwide under similar conditions.
\end{abstract}

Keywords: Photovoltaic; Economic viability; Life cycle cost; $\mathrm{CO}_{2}$ emission; Risk assessment

\section{Background}

The major conventional sources for powering underground water pumps are either fossil fuel generators or electricity from a nearby grid. Both methods have considerably expensive running costs and varying implementation costs depending on the location, nature and budget of the water project. The choice of this concept over conventional means of energy regarding cost over a period of time as well as $\mathrm{CO}_{2}$ emission is gaining more and more popularity around the world, especially where electricity is either unavailable or unreliable. Several papers regarding these issues were found in the open literature and are summarised as follows:

\footnotetext{
* Correspondence: mebaid2@philadelphia.edu.jo

2Philadelphia University Jordan, Amman, Jordan

Full list of author information is available at the end of the article
}

Thomas (1993) stated that the method of the life cycle cost (LCC) is an efficient method to be used to evaluate the financial viability of a PV water pumping solar system. Senol (2012), Abu-Aligah (2011), Mahjoubi et al. (2010), Odeh et al. (2006), Mahmouda and Natherb (2003) and Kolhe et al. (2002) all studied the economical aspects of solar photovoltaic (PV) water pumping compared to diesel genset, by using the method of LCC. The results indicated that the PV solar water pumping, in terms of cost, is better than the diesel pumping systems.

The studies of Purohit (2007), Firatoglu and Yesilata (2004) Short and Oldach (2003) proved that the financial viability of solar PV energy with respect to the other conventional options, electric or diesel genset, for the pumping of water is the principal barrier which slows down its broad adoption. Kordab (2007) studied the 
priority options of photovoltaic systems for water pumping in rural areas in the Economic and Social Commission for Western Asia (ESCWA) - the United Nations, member countries by using cost analysis method to determine the cost of the kilowatt hour produced compared with diesel fuel prices during the life of the PV systems (assumed to be 20 years). The study stated that the PV systems are competent with other options when the total cost of the PV system is less or equal to US $\$ 7 / \mathrm{W}_{\mathrm{p}}$.

Alsema and Nieuwlaar (1997) conducted a life cycle assessment LCA which involves the comprehensive assessment of all environmental impacts throughout the life cycle of the PV system. The concept of energy pay back time (EPBT) was also discussed. Eventually, the conclusions revealed that, from an environmental point of view, the use of PV as a replacement for fossil fuel-based electricity generation has significant environmental benefits and there seems to be no significant bottlenecks that cannot be overcome. Goodrich et al. (2011) studied all aspects regarding the PV system components manufacturing costs. His study depended on first-hand data from industry stakeholders, supplemented with public data sources. A sensitivity analysis in the identification of cost drivers was also conducted, along with discussing the direct and indirect costs.

Tamrat (2007) analysed the viability of renewable energy technologies for rural electrification in selected sites in Ethiopia. The results showed that the use of microhydro power generation is preferable. But in most areas where the wind speed was below $5 \mathrm{~m} / \mathrm{s}$ with no stream or river available, PV system would be the best choice. Meanwhile, Elker (2005) and Heliknson et al. (1991) found that photovoltaic power is more cost-competitive when used to power a micro irrigation system as compared to an overhead sprinkler system. The work of Qoaider et al. (2010) was to investigate the economic feasibility of photovoltaic technology to supply the entire energy demands to off-grid irrigated-farming-based communities in the arid regions. Chandraskar and Kandpal (2005) presented a framework for studying the effect of several existing and proposed financial and fiscal incentives on the effective capital cost of a renewable energy system to the user. The results showed that the provision of income tax benefit on the amount of investment made by the user on the purchase and installation of renewable energy system is likely to be more attractive than the provision of low interest loan.

Krauter and Ruther (2003) conducted a $\mathrm{CO}_{2}$ comprehensive balance within the life-cycle of a photovoltaic energy system. Calculations of the possible effect on $\mathrm{CO}_{2}$ reduction by PV energy systems were made in Brazil and Germany. Roy (2012) demonstrated that the test results on the application of solar PV DC system provided satisfactory performance on water pumping, and moreover, it is user and environmentally friendly. Together with decreasing PV module costs and increasing efficiency, PV is getting more pervasive than ever.

Mahjoubi et al. (2013) investigated the economic viability of remote PV water pumping systems in the desert of Southern Tunisia, which will have to satisfy an average daily volume of $45 \mathrm{~m}^{3}$ throughout the year compared with diesel genset by using the method of the LCC. Their study indicated economic viability of PV water pumping systems in the desert of Tunisia. Similar work by Grima (2014) was carried out in Ethiopia to study the economic feasibility of water pumping. The result showed that direct coupled PV pumping system is cost-effective in terms of life cycle cost and technologically feasible for rural water supply by virtue of its very low running cost and high reliability of the component and the system as a whole.

Sahin and Rehman (2012) studied economical feasibility of producing energy using PV solar panels of 9.99$\mathrm{kW}$ total capacity and utilizing it to pump water at five locations in Saudi Arabia. They found that the cost of water pumping to vary between 2 and $3 \mathrm{cents} / \mathrm{m}^{3}$. Parajuli et al. (2104) presented a financial model to compare three technical scenarios of water pumping using petrodiesel, jatropha-based biodiesel and solar photovoltaic pumps to pump drinking water in one of the remote rural village of Nepal. The financial model is carried out to compare the alternatives on the basis of the economic parameters: net present value, equivalent annualised cost and levelised cost of water pumping. Analysis is carried out considering different influential parameters: water head, discharge, incentives on the investments, which have effects on the cost of pumped water. Likewise, in case of biodiesel-based system, different yield rates of jatropha plants are also considered in estimating the cost of producing biodiesel. It was found that biodiesel-based system is more attractive than that of the diesel-based pump but still remains more expensive than that of solar pump. From the technical perspective (reliability and easiness in operation) and economic evaluation of the technical alternatives, solar pumping system was found to be the most viable solution to pump drinking water in the project area.

All previous studies were addressed to small PV water pumping systems. However, as the authors are aware of, no pre-feasibility assessment has been done before in order to assess large-scale off-grid-connected PV power plant (13 MW) for underground water pumping, which made this research a challenge. The aim of this work is to compare the costs of pumping the underground water of five powering options. These are PV, grid, genset and combinations of $\mathrm{PV} /$ grid and $\mathrm{PV}$-genset by using the method of the LCC. The question of which one of the system is most cost effective is the subject of this study. 
It is based on field results taking into account maintenance and operation costs, fuel costs, salvage costs, in addition to initial costs. The present value of the life time costs of the different methods of pumping was used for comparison.

This current work presents a comprehensive study as it addresses, in addition to economic analysis, the issues of environmental impact due to $\mathrm{CO}_{2}$ emissions and risk assessment. This project is one of the largest underground water pumping using PV system in the region. Moreover, the water is being pumped from different number of wells (55) covering ground surface area of about $750 \mathrm{~km}^{2}$ (Ellington et al. 2015). Therefore, it can be considered as a leading project in terms of design and energy management. The authors feel that this study may help the decision-makers to select the most suitable power option out of five power alternatives that have not been addressed before for large underground water pumping systems and can be applied for similar cases globally. It should be noted here all the required data for accomplishing this work are taken from a previous paper published by the authors (Ebaid et al. 2013), which is related to the sizing of the PV components.

\section{Disi wellfield}

\section{Wellfield location}

The area of Disi wellfield is located in the south of Jordan, 340-350 km away from Amman (GAMA Enerji Co. 2999) as shown in Fig. 1. The wellfield area is more than $20-30 \mathrm{~km}$ away from the nearest electrical grid with some wells almost $70 \mathrm{~km}$ far. Fifty-five water production wells were arranged in 12 main lines forming a plant-shaped distribution, which helped in ensuring better access to each well and covering as much as possible of the aquifer area.

\section{Selection criteria of design wells}

The 55 wells where categorized into five main groups depending on its altitudes, and the maximum altitude difference was found to be 132 meters. If a difference of $25 \mathrm{~m}$ in altitude would be assumed as significant in categorizing the wells, four groups are formed: A, B, C and D. One well was selected from each of the four groups. Those selected wells were geographically optimized to represent the whole Disi wellfield that will help construct a proper solar map for all Disi area. The selected wells were as follows: W25 of group A, W39 of group B, W34 of group C and W47 of group D.

\section{Wellfield pumping head}

For completion of work, some design data, about the pumping system is presented here. This includes the total pumping heads (TPH) of each designed well, at a continuous flow rate of $Q=80^{\mathrm{l}} / \mathrm{s}$ or $288^{\mathrm{m}^{3}} /$ hour according to the agreed project specifications for the next 25 years. TPH will be taken at the end of each 5 year period and then added to the initial conditions of the first period (the current starting conditions of the project). Withdrawal of thousands of cubic meters per day is an unnaturally rapid change in a groundwater system and results in some

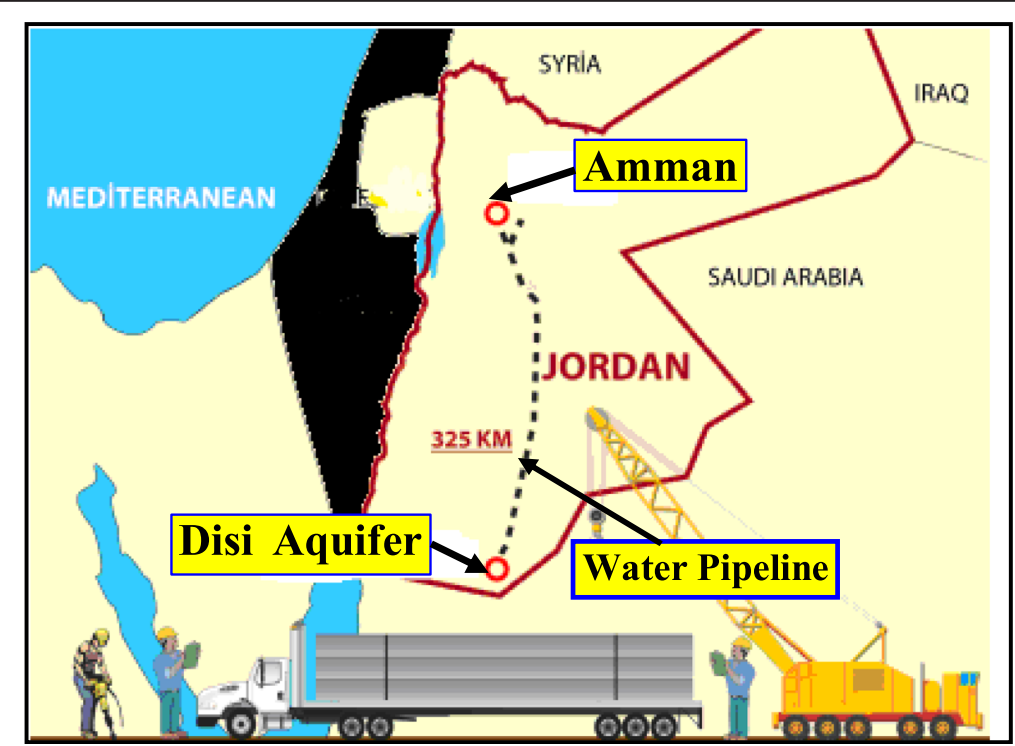

Fig. 1 Disi aquifer location in south of Jordan, Gama Energy Co. (GAMA Enerji Co. 2010) 
major perturbations of the water reserves. Initially, water level drops very rapidly in the immediate vicinity of the well. This lowering of the water level is known as drawdown and may amount to many tens of meters. The pumping head of each well is being directly affected by the continuous withdrawal of water that causes drawdown. Figure 2 illustrates the predicted water drawdown from the selected four design wells.

To identify the reason behind the rapidly starting drawdown of wells, the time-drawdown hydro-geological analysis should be comprehended, which includes understanding the development procedures of the cone of depression (Heath 1983) which occurs in an aquifer when groundwater is pumped from a well.

To correctly select a proper pump, the expected pumping heads for the next 25 years were studied through intensive hydro-geological analysis of the aquifer, conducted in the feasibility study phase of the project. The know-how of these data was considered as classified Disi project specifications by the Turkish GAMA Enerji Co. 2010. which is responsible for building and operating the project. To ensure that the selected pump will meet all head or discharge pressure requirements, the TPH has to be calculated (Eq. 1), which is being directly affected by the continuous withdrawal of water that causes drawdown (Ebaid et al. 2013). Based on the above, a submersible pump is selected and supposed to last 25 years according to its specification (Table 1).

$$
\mathrm{TPH}=\mathrm{SWL}+\mathrm{DD}+\mathrm{H}_{\mathrm{L}}(\mathrm{m})
$$

Where THP is the total pumping head (m), SWL is the static water level (m), DD is the drawdown $(\mathrm{m})$ and $\mathrm{H}_{\mathrm{L}}$ is the head loss in the well due to pipes and fittings, and

$$
H_{L}=f\left(\frac{L}{D_{i}}\right)\left(\frac{V^{2}}{2 g}\right)(m) \quad(\text { Darcy-Weisbach })
$$

where $f$ is the friction factor, $L$ is the total length of pipe (m), $D_{i}$ is the inner diameter of pipe $(\mathrm{m})$ and $V$ is the velocity of water $(\mathrm{m} / \mathrm{s})$.

For the current pumping case, pumping lines connecting the semi axial submersible vertical pump (Flowserve Hamburg Company) and the pressure tank are already selected to be of galvanized steel pipes with internal diameter $D_{i}$ of $40 \mathrm{~cm}$ and internal roughness $e_{t}$ of $0.15 \mathrm{~mm}$, friction factor $f$ can be obtained using Moody chart, hence head loss $H_{L}$ can be obtained from Eq. 2 above and graphically shown in Fig. 3.

It can be seen that the head losses are clearly not significant, and it can almost be neglected when estimating the pumping head. Then, the total pumping heads (THP) of design wells for the next 25 years of water pumping can be directly calculated from Eq. 1 and shown in Fig. 4.

It should be noted here that the TPH is lower than the SWL. The reasons are that the head loss is very small as shown in Fig. 3 and the effect of the drawdown of water during pumping which decreases with head increase. In addition to that, the water is not replenished.

\section{Water power, pump power and motor power}

Water power $P_{W}$ is the power required to raise water at a specified flow rate $\dot{Q}$ against a specified head, assuming $100 \%$ pump efficiency $\eta_{P}$ and this can be calculated by Eq. 3,

$$
P_{W}=(\rho g)(\dot{Q})(\mathrm{THP})(k W)
$$

Pump power $P_{P}$ can be either the power developed at the motor shaft (motor output) or that absorbed at the pump shaft (pump input), and it depends on the pump efficiency $\eta_{P}$ according to Eq. 4,

$$
P_{P}=\frac{P_{W}}{\eta_{P}}(k W)
$$

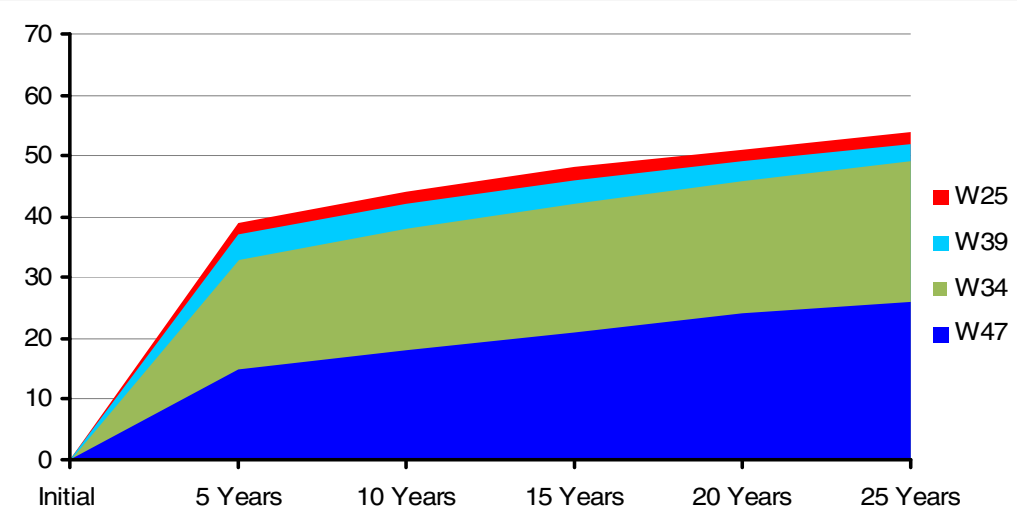

Fig. 2 Predicted water drawdown of design wells 
Table 1 Predicted trend of well pump head variation for continuous 25 years of pumping (Ebaid et al. 2013)

\begin{tabular}{lllllll}
\hline Well number & Current actual SWL $(\mathrm{m})$ & In 5 years $(\mathrm{m})$ & $\ln 10$ years $(\mathrm{m})$ & $\ln 15$ years $(\mathrm{m})$ & $\ln 20$ years $(\mathrm{m})$ & $\ln 25$ years $(\mathrm{m})$ \\
\hline W25 & 101.6 & 252.0 & 260.5 & 266.4 & 269.8 & 272.3 \\
W39 & 128.5 & 263.4 & 271.5 & 277.1 & 280.3 & 282.7 \\
W34 & 147.4 & 245.0 & 252.4 & 257.6 & 260.5 & 262.7 \\
W47 & 161.4 & 238.2 & 242.2 & 245.0 & 246.6 & 247.7 \\
\hline
\end{tabular}

Motor power $P_{m}$ is that needed by the electrical motor to operate the pump, it differs according to the motor efficiency $\eta_{m}$ as shown in Eq. 5 below:

$$
P_{m}=\frac{P_{P}}{\eta_{m}}(k W)
$$

Using Eqs. 3, 4 and 5, motor power $P_{m}$ design values are obtained and drawn graphically in Fig. 5. Pump and motor efficiencies were taken as 77.9 and $89 \%$, respectively, from the specification of the originally selected submersible pump.

\section{Methods}

\section{Economic analysis}

The investment costs of PV systems are still relatively high (Zwaan 2003), although this cost is decreasing rapidly as a result of technology improvements and economies of scale. High investment costs, or total system costs, represent the most important barrier to PV deployment today. Total system costs are composed of the sum of module costs including mounting structures, inverters, batteries, cabling and power management devices.

While the costs of different technology module types vary on a per watt basis. These differences are less significant at the system level, which also takes into account the efficiency and land-use needs of the technology. Total system costs are sensitive to economies of scale and can vary substantially depending on the type of application according to the International Energy Agency (IEA) (International Energy Agency (IEA) 2009).

In the following sections, a complete economic analysis will be conducted for each proposed energy alternative and the final values will be compared to determine the most cost-effective alternative. The method to be used in this study is the life cycle cost LCC method. Life cycle cost analysis (LCCA) key elements can be broken down into the following three variables: the costs of ownership, the operation costs and the salvage value. The period of time over which these costs are incurred and the discount rate that is applied to future costs are to be equated with present-day costs.

\section{Project alternatives}

Prior to beginning an LCCA, project alternatives need to be established. These alternatives were selected to be distinctly different and viable solutions for pumping water from Disi wells. The chosen alternative is usually the most reasonable and cost-effective solution for pumping purposes, but as the comparison includes renewable-versus-conventional energy sources, the selection would more likely be biased for the PV system as environmental and sustainability factors will be included. In this work, five powering scenarios for the submersible pumps are to be discussed in terms of cost effectiveness and installation viability, those five scenarios are as follows:

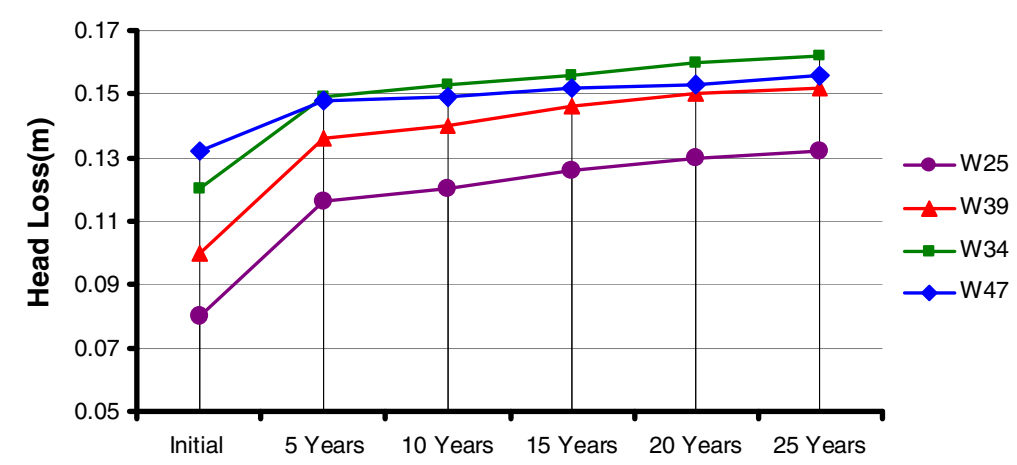

Fig. 3 Calculated head loss of design wells for next 25 years of pumping 


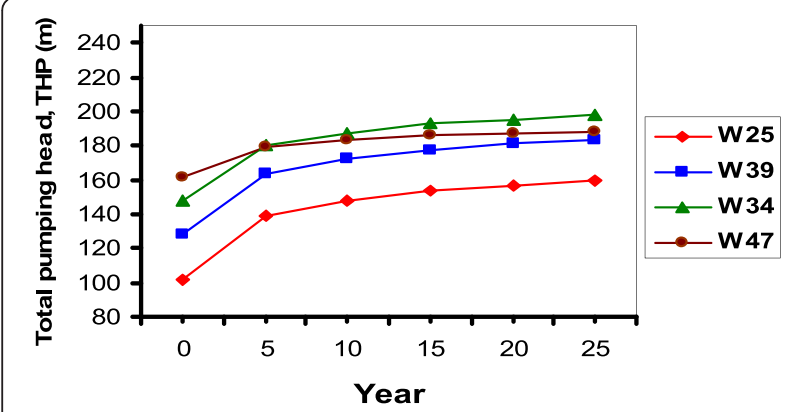

Fig. 4 Total pumping head (TPH) of design wells for the next 25 years of pumping

1. Twenty-four-hour PV system, using batteries for night-time operation.

2. Twenty-four-hour electrical grid system. The electrical grid is very far and it would need a huge infrastructure to be available, however, this option will still be considered.

3. Twenty-four-hour diesel genset system which usually requires the use of two generators to back-up each other.

Two more scenarios will be considered, combining the daytime operation of the PV system with night-time operation for each of the other two conventional systems:

1. Twelve-hour PV, 12-h diesel genset system.

2. Twelve-hour PV, 12-h electrical grid system.

\section{Initial system costs (PV, genset and electrical grid)}

Costs that will be incurred prior to the running of the system are initial investment costs. All initial costs are to be added to the total LCCA at their full value. However, some parameters that will be used in the LCC should be stated here. These are the following:

1. Real interest rate $\left(i_{r}\right)$ : according to Eq. 6, Fisher (International Monetary fund 2010) stated that the

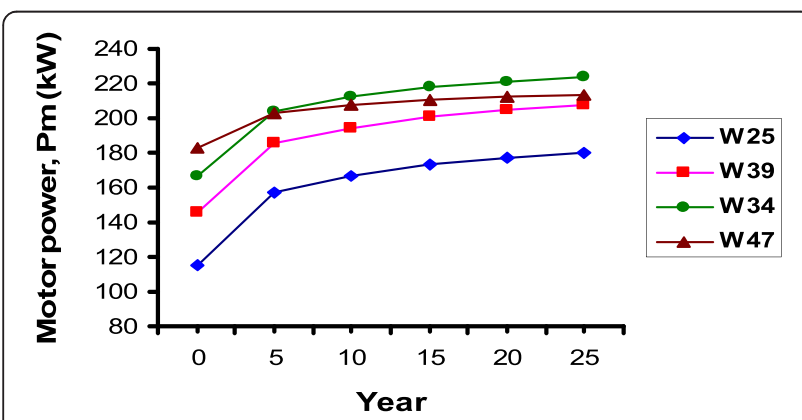

Fig. 5 Motor power $P_{m}$ of design wells at $\eta_{p}=77.9 \%$ and $\eta_{m}=89 \%$ at an interval of 5 years real interest rate is approximately the nominal interest rate $i$ minus the expected inflation rate $i_{f}$ :

$$
1+i_{r} \cong(1+i)-\left(1+i_{f}\right)
$$

In this work, an optimistic estimation of $1 \%$ real interest rate can be adequate and close the low values in the past few years of the Jordanian economy (Fisher 1977).

2. Present worth value $(P W)$ : the present worth value of an annuity $A$ (periodic cash flows) can be calculated according to Eq. 7:

$$
\mathrm{PW} \text { of Annunity }=\frac{P}{A}(A, i, n)=\left[\frac{1-\frac{1}{(1+i)^{n}}}{i}\right]
$$

where $P$ is the present value, $A$ is the present value of an annuity and $n$ is the total life (years).

The present value of any money to be received in the future can be computed by Eq. 8 :

$$
\mathrm{PW} \text { of Future }=\frac{P}{F}(F, i, n)=\frac{1}{(1+i)^{n}}
$$

where $F$ is the future value.

The frequency of compounding affects the present value of cash flows. Hence, stated interest rate can deviate significantly from the true interest rate. However, to simplify the calculations of this study, the compounding would be assumed to happen annually in all cases.

\section{PV component initial costs}

For the PV system, the cost of each major component in terms of user specified variables is to be determined based on the design specifications of the PV components as summarized below:

- PV panels: poly-crystalline modules, MaxPower CS6X-300W $_{P}$ solar panel type from Canadian Solar Inc.

- Inverter: 250-kW inverter Sunny Central 250U manufactured by SMA Inc.

- Batteries: 8 V Rolls Series 5000 battery with a 20-h rated capacity of $820 \mathrm{Ah}$ from the American manufacturer Surrette

- Charge controllers: FLEXmax 80, the voltage-adjustable $80 \mathrm{~A}_{\mathrm{DC}}$

The calculations for sizing the PV system, inverters, batteries and charge controllers and PV areas are all presented in a previous paper related to this work (Ebaid et al. 2013). It should be mentioned here that the listed number of the PV panels is calculated based on the 
actual DC power produced after identifying the power losses (temperature loss factor, battery loss factor, cable loss factor, and mismatch loss factor). Another important issue is the life-time efficiency of the PV panels, which will be reduced down to $80 \%$ of the total peak power reaching the panel's rated life of 25 years.

Also, for the total number of batteries required, the calculations are based on the factors that affect their performance (discharge rate and depth of discharge, days of autonomy, aging, temperature, and the round trip efficiency specified by the manufacturer, $80 \%$ ). Dust accumulation problem on PV surfaces was accounted for as a $5 \%$ power loss factor (Ebaid et al. 2013). The land availability would not be a problem for the case of this study at Disi area as this desert areas will be most probably offered for free by the government to the project. So, land costs would conveniently be discarded. Based on that, the major components, which include type and rating, quantities, the unit price cost and the total cost, are all listed in Table 2 below.

\section{Genset initial costs}

A $250-\mathrm{kW}$ generator would be very suitable for the power requirements. From prior experience with the Jordanian market of generators, Caterpillar gensets (Worldwide Power Products 2012) have good reliability with continuously available service and spare parts, so a Caterpillar C9 $250 \mathrm{~kW}$ generator was selected with an estimated price (shipping and customs included) of US $\$ 100,000$. Since two generators will be needed to backup each other, the total initial cost of this alternative would be US $\$ 200,000$.

\section{Electrical grid through Disi desert initial costs}

Costs for establishing a grid network in Disi desert would certainly be very expensive, especially as the distance from the nearest electrical grid increases. According to confidential data from the National Electric Power Company NEPCO Ltd. and the Electrical Distribution Company EDCO Ltd. 2011 (International Monetary fund 2009), Disi project will require establishment of one main station, 55 transforming substations from 33 to $0.415 \mathrm{kV}$ (500 kVA) on each well and about $150 \mathrm{~km}$ of transmission lines.

The estimated cost per kilometre of transmission lines (including the columns, cables, insulators etc.) equals about US\$21,429, with an additional cost of US\$14,286 per kilometre to cover other miscellaneous costs such as road opening, labour and transportation. With $150 \mathrm{~km}$ total distance that the grid lines should cover (considering the $1.5 \mathrm{~km}$ spacing between the 55 wells, distance to the main substation and additional distance for line detours due to the hard terrain of Disi), the total estimated transmission line cost for the 55 wells would equal US $\$ 5,375,143$. Figure 6 below shows the suggested trails that lead to each design well from the main station location (indicated by the black arrow).

The total estimated cost of the 55 transforming substation is US $\$ 785,714$. For the main station, cost is approximated at US $\$ 2,857,143$. Total estimated cost

Table 2 Initial PV component costs (Ebaid et al. 2013)

\begin{tabular}{|c|c|c|c|c|c|c|}
\hline \multirow[t]{3}{*}{ Well number } & \multicolumn{6}{|c|}{ PV component costs for the PV alternative (prices in USD) } \\
\hline & \multicolumn{3}{|c|}{ PV panels $\left(300 W_{P}\right)+$ structure } & \multicolumn{3}{|c|}{ Inverters (250 kW, SMA Inc.) } \\
\hline & Quantity & Unit price & Total & Quantity & Unit price & Total \\
\hline W25 & 2969 & 500 & $1,484,500$ & 1 & 54810 & 54810 \\
\hline W39 & 3503 & 500 & $1,751,500$ & 1 & 54810 & 54810 \\
\hline W34 & 3847 & 500 & $1,923,500$ & 1 & 54810 & 54810 \\
\hline W47 & 3827 & 500 & $1,913,500$ & 1 & 54810 & 54810 \\
\hline \multirow[t]{2}{*}{ Well number } & \multicolumn{3}{|c|}{ Batteries (8 V, $820 \mathrm{Ah})$} & \multicolumn{3}{|c|}{ Charge controllers (FlexMax 80, $24 \mathrm{~V}, 80 \mathrm{~A}_{\mathrm{DC}}$ ) } \\
\hline & Quantity & Unit price & Total & Quantity & Unit price & Total \\
\hline W25 & 1186 & 1000 & $1,186,100$ & 395 & 571 & 225,545 \\
\hline W39 & 1399 & 1000 & $1,399,100$ & 466 & 571 & 266,086 \\
\hline W34 & 1537 & 1000 & $1,537,100$ & 512 & 571 & 292,352 \\
\hline W47 & 1529 & 1000 & $1,529,529$ & 510 & 571 & 291,210 \\
\hline \multicolumn{7}{|c|}{ Gross total PV component costs (prices in USD) (PV panels + structure, inverters, batteries and charge controllers) } \\
\hline W25 & $2,950,855$ & & & & & \\
\hline W39 & $3,471,496$ & & & & & \\
\hline W34 & $3,807,762$ & & & & & \\
\hline W47 & $3,789,049$ & & & & & \\
\hline
\end{tabular}




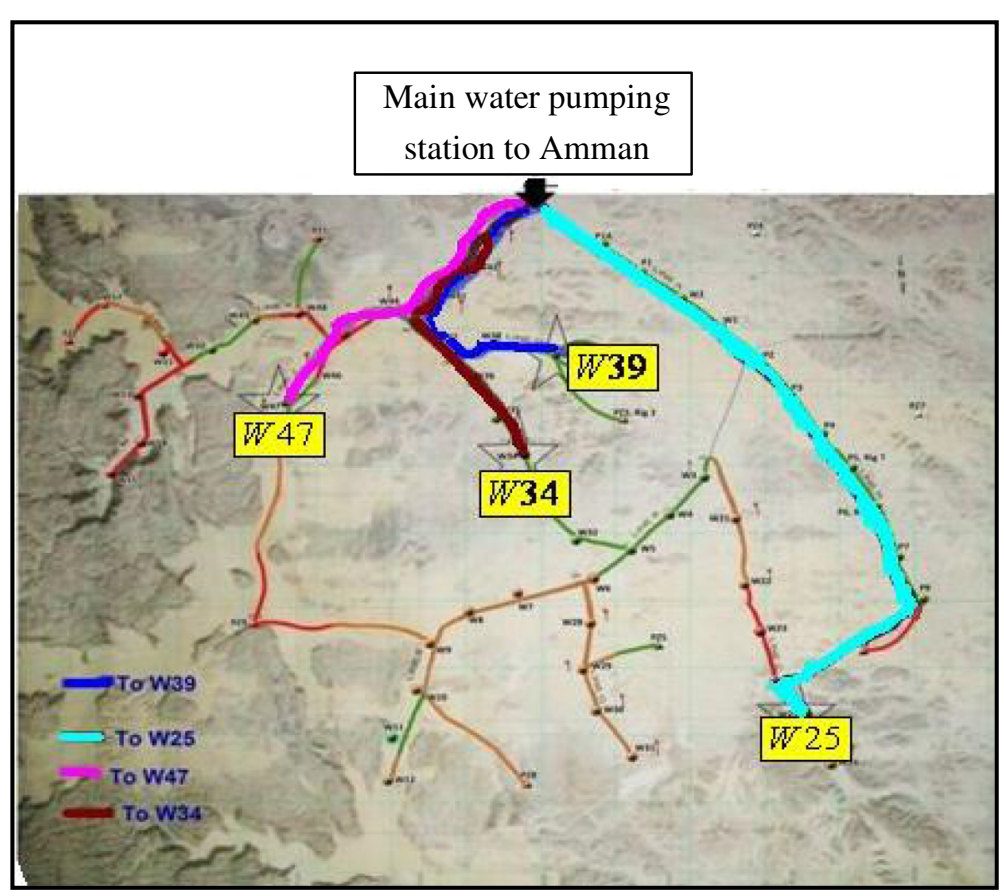

Fig. 6 Electrical Distribution Company (EDCO) (International Monetary fund 2009) intended trails for electrical grid to each design well

for the grid with a $10 \%$ other cost factor equals approximately US\$9, 900,000. Dividing the cost upon the 55 production wells, each well would have an initial cost of US\$180,000.

\section{Operation costs}

The second step in the completion of the LCCA is to define all future operation costs of each alternative. The operation costs are annual costs of manpower, overhead and fuel involved in the operation of the facility. It excludes maintenance, transport and repair costs. All operation costs are to be discounted to their present value prior to addition to the LCCA total.

\section{PV system operation costs}

Most PV system operational costs are related to overheads and labours. It includes on-site guards and labourers for cleaning the modules and regular component checks, especially for the batteries. This cost according to Goodrich et al. (2011) could be three times the usual overheads of electrical systems. Also, Goodrich et al. (2011) stated that the life cycle labour and overhead costs can be estimated to equal US $\$ 0.49 / \mathrm{W}_{\mathrm{p}}$ for ground-mounted panels. In this work, lifecycle cost of only US $\$ 0.2 / \mathrm{W}_{\mathrm{p}}$ is to be considered to compensate for additional manpower and skill needed. Considering the total number of $300 \mathrm{~W}_{\mathrm{p}}$ of PV panels used at each design well, a total operational cost for the PV alternative, during the 25 years of operation, would equal US\$204,286 for W25; US\$234,286 for W39; US\$252,857 for W34 and US\$241,429 for W47, respectively.

\section{Genset operation costs}

The main source of cost for the genset alternative is diesel fuel. Manpower and overhead costs for this alternative are relatively small and assumed to be included in the final contingency factor. As the prices of fuel worldwide are growing up, its expenses are gaining more and more concern regarding operational costs of systems as fuel is directly affected by inflation rates.

Fuel consumption of a diesel genset is related to the load factor of its engine, which is the ratio of required power output to the maximum rated power output of the genset. As the power demand increases, fuel consumption increases accordingly. Special charts for fuel consumption versus the load factor are usually available in the specification sheets of equipment. For the selected Caterpillar C9 $250 \mathrm{~kW}$ genset, the approximated General Fuel Consumption Chart, (Worldwide Power Products 2012) can be used as a reference at the load factors indicated in Table 3.

Table 3 Fuel consumption versus load factor for diesel gensets GAMA Enerji Co (2010)

\begin{tabular}{lllll}
\hline $\begin{array}{l}\text { Genset size } \\
(\mathrm{kW})\end{array}$ & \multicolumn{4}{l}{ Diesel consumption $(\mathrm{L} / \mathrm{h})$} \\
\cline { 2 - 5 } & $\begin{array}{l}\text { One-fourth } \\
\text { load }\end{array}$ & $\begin{array}{l}\text { One-half } \\
\text { load }\end{array}$ & $\begin{array}{l}\text { Three-fourths } \\
\text { load }\end{array}$ & $\begin{array}{l}\text { Full } \\
\text { load }\end{array}$ \\
\hline 200 & 18 & 29 & 42 & 55 \\
230 & 20 & 33 & 47 & 63 \\
250 & 22 & 36 & 51 & 68 \\
300 & 26 & 43 & 61 & 81 \\
\hline
\end{tabular}


Relating the diesel consumption values to the power demand of wells, bearing in mind that only one generator will be running at a time, Table 4 shows the genset load factors that will be resulted at each design well and the estimated amount of diesel consumed over the whole study period.

The life cycle fuel consumption was calculated by summing the consumptions of all phases of the study period (25 years). As per the phase fuel consumption, it was computed by multiplying the litres/year, at the beginning of each phase, by the length of that phase (5 years). In each year of the study period, the diesel prices are being affected by inflation rates. Therefore, the pricing of fuel costs should be made on present worth bases using the real interest rate $i_{r}=1 \%$ in the time value of money, International Monetary fund, and report no. 09/159 (International Monetary fund 2009). Then, to calculate the present worth (PW), each fuel consumption period should be considered separately and its fuel costs are to be reduced to present worth, similar to the following sample of calculations for well (W25) at the current diesel cost is US\$0.73/litre.

$$
\begin{aligned}
\text { Total diesel cost }= & \text { Diesel cost } \times[(315,360+315,360) \\
& \times(P / A)(A, 1 \%, 5)+(446,760) \\
& \times(P / A)(A, 1 \%, 20) \times(P / A)(F, 1 \%, 5)] \\
= & 0.73 \times[(315,360+315,360) \times 4.853 \\
& +(446,760 \times 18.046 \times 0.9515)] \\
= & \mathrm{US} \$ 7,834,430 \text { for } 25 \text { years of operation } \\
& \text { at W25 }
\end{aligned}
$$

Similarly, for the rest of design wells, costs of diesel for the whole 25 year operation period are US\$8,855,714 for W39 and US\$9,357,143 for both W34 and W47.

\section{Electrical grid operation costs}

The electrical grid system operation costs will mainly result from the electricity tariff (electricity price) in cent/kWh, with an additional overhead and manpower cost of $2 \%$ per year of the initial grid cost. Considering the initial cost indicated in section "Electrical grid through Disi desert initial costs", overheads and manpower cost about US\$3,571/year for each well, totalling US\$80,000 per well for the whole study period. The water pumping tariff equals 60 cent $/ \mathrm{kWh}$ according to the retail tariff of electricity according the National Electric Power Company of Jordan (NEPCO) (National Electric Power Company of Jordan NEPCO 2011). Addition of taxes and the soon-expected rise in electricity prices would approximately turn this value to 64 cent $/ \mathrm{kWh}$. According to the historical data of electricity prices in Jordan at certain periods, the rise of electricity tariffs has been fluctuating up and down due to the rate of inflation of those periods. In this study, the electricity tariff is assumed to be affected only by an inflation rate of $5 \%$ per year, Blignaut et al. (Blignaut et al. 2005).

Yearly values can be computed through fitting the motor power data using Easy Fit 5.5 Professional software into a probability distribution, and then generate yearly data according to the parameters of the fitted distribution. Results of generated motor power data along

\begin{tabular}{|c|c|c|c|c|c|c|}
\hline \multirow[t]{4}{*}{ Well number } & \multicolumn{6}{|c|}{ Real load factor (\%) } \\
\hline & \multicolumn{6}{|c|}{ Design load factor (ratio) } \\
\hline & \multicolumn{6}{|c|}{ Fuel consumption (L/year) - 24-h genset scenario } \\
\hline & $\begin{array}{l}0-5 \\
\text { Years }\end{array}$ & $\begin{array}{l}5-10 \\
\text { Years }\end{array}$ & $\begin{array}{l}10-15 \\
\text { Years }\end{array}$ & $\begin{array}{l}15-20 \\
\text { Years }\end{array}$ & $\begin{array}{l}20-25 \\
\text { Years }\end{array}$ & $\begin{array}{l}\text { Life cycle diesel } \\
\text { consumption }(\mathrm{L})\end{array}$ \\
\hline \multirow[t]{3}{*}{ W25 } & $0.46 \%$ & $0.63 \%$ & $0.67 \%$ & $0.69 \%$ & $0.71 \%$ & $10,512,000.0$ \\
\hline & One half & Three fourths & Three fourths & Three fourths & Three fourths & \\
\hline & 315,360 & 446,760 & 446,760 & 446,760 & 446,760 & \\
\hline \multirow[t]{3}{*}{ W39 } & $0.58 \%$ & $0.74 \%$ & $0.78 \%$ & $0.80 \%$ & $0.82 \%$ & $12,658,200.0$ \\
\hline & Three fourths & Three fourths & Three fourths & Full & Full & \\
\hline & 446,760 & 446,760 & 446,760 & 595,680 & 595,680 & \\
\hline \multirow[t]{3}{*}{ W34 } & $0.71 \%$ & $0.86 \%$ & $0.89 \%$ & $0.91 \%$ & $0.93 \%$ & $14,147,400.0$ \\
\hline & Three fourths & Full & Full & Full & Full & \\
\hline & 446,760 & 595,680 & 595,680 & 595,680 & 595,680 & \\
\hline \multirow[t]{3}{*}{ W47 } & $0.73 \%$ & $0.81 \%$ & $0.83 \%$ & $0.84 \%$ & $0.85 \%$ & $14,147,400.0$ \\
\hline & $3 / 4$ & Full & Full & Full & Full & \\
\hline & 446,760 & 595,680 & 595,680 & 595,680 & 595,680 & \\
\hline
\end{tabular}
with the corresponding $\mathrm{kWh}$ electrical consumption and the total yearly prices are all shown in Figs. 7 and 8. The computed total study period costs in Fig. 8 are brought back to present worth and will be directly used in the final LCCA of this alternative.

Table 4 Estimated diesel fuel consumption for each design well in each pumping phase 


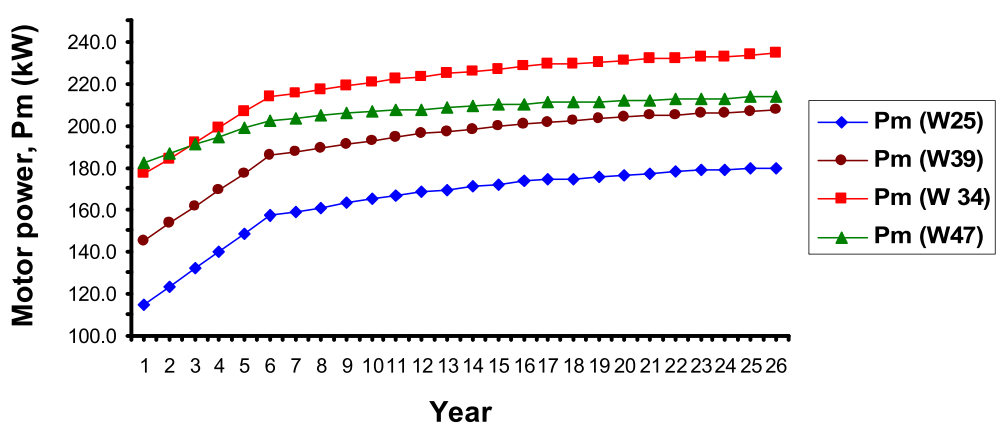

Fig. 7 Yearly motor power $P_{m}$ of design wells

\section{Maintenance and repair costs}

For simplicity, maintenance costs and repair costs have been combined in the LCCA; however, it should be understood that there is a distinction between those two costs. Maintenance costs are scheduled costs associated with the upkeep of the facility, while repair costs are unanticipated expenditures that are required to prolong the life of equipment system without replacing them.

\section{PV component maintenance and repair costs}

Maintenance and repair costs for a PV system can usually be estimated as $10-15 \%$ of the operational costs for the whole life of the PV system, Hansen et al. (2005). For this work, it will be conservatively taken as $12 \%$, which would be equal to US $\$ 24,514$, US $\$ 28,114$, US $\$ 30,343$ and US $\$ 28,971$ for wells W25, W39, W34 and W47, respectively.

\section{Genset maintenance and repair costs}

Based on Caterpillar (CAT) genset specifications and the on-site experience of preventive maintenance frequency for CAT generators (being currently used at the well construction phase); lubrication and fuel system service is needed every 200 working hours using standard grade of engine oil (though, it is usually better to be replaced every 150 working hours under severe running conditions). The recommended oil by the manufacturer is CAT DEO SAE 15 W40. Coolant and air filters' replacement is due every 1,000 working hours and battery replacement every 10,000 working hours. Table 5 lists the estimated amounts and costs of preventive-maintenance materials and the total costs required throughout the study period by assuming $1 \%$ real interest rate. The estimated genset maintenance cost was multiplied by $30 \%$ to compensate for spare parts that would be necessary for repairs and overhauls, along with manpower and overheads related to maintenance work. Hence, the total approximated cost would equal US\$590,948 per well for the whole study period.

\section{Electrical grid maintenance and repair costs}

The electrical grid requires on-site maintenance, repair, testing and troubleshooting frequently. Due to large variability in the grid maintenance demands, it can be suitably combined with the addition and replacement costs that will be discussed in Section 2.5.3.

\section{Equipment replacement and addition costs}

Replacement and addition costs are anticipated expenditures to major system components that are required to maintain the operation of a facility.

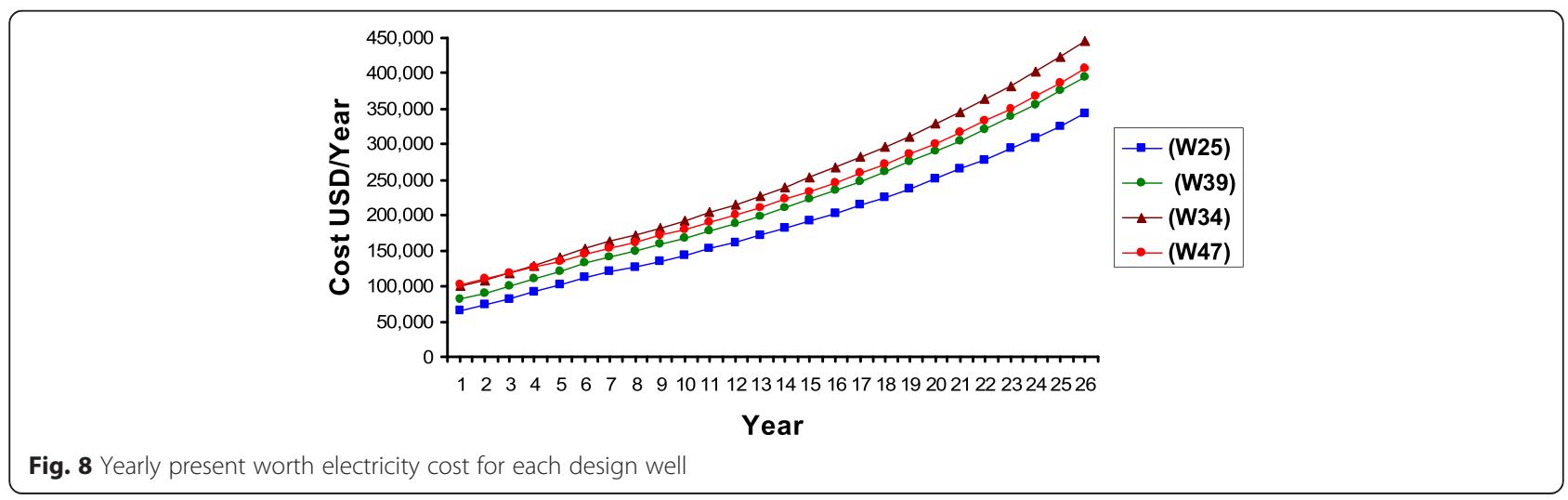


Table 5 Estimated quantities and costs of preventive maintenance material for genset

\begin{tabular}{llllll}
\hline Item & No. of changes/year & Quantity/change & Price/item (US\$) & Cost/year (US\$) & Cost/study period (US\$) (25 years) \\
\hline Engine oil & 43 & 35 L/change & 7 & 10,535 & 263,375 \\
Oil and fuel Filters & 43 & 1 set/change & 114 & 4,902 & 122,550 \\
Coolant & 8 & 80 L/change & 3 & 1,920 & 48,000 \\
Air Filters & 8 & 1 piece/change & 71 & 568 & 14,200 \\
Batteries & 1 & 2 piece/change & 129 & 258 & 6,450 \\
& Total cost (US\$) = Maintenance cost + Spare parts costs & & $(454,575)+(454,575 \times 30 \%)=$ US\$590,948
\end{tabular}

Source of prices: data collected verbally from several suppliers of CAT servicing material

\section{PV component replacement and addition costs}

Major PV system components that could be considered for the replacement and addition costs include inverters, PV panels and batteries. Life of inverters is usually taken as 10-15 years, Hansen et al. (2005), which requires the system inverter to be replaced one time at the 15 th year. The photovoltaic panels will not require replacement during the system lifetime since their expected life is 25 years. However, due to increased power requirements with time which is directly proportional to the water requirements of the well, and decreased panel efficiency (aging power of PV panels at a degradation rate $0.8 \%$ / year should be taken into account), additional PV panels will be needed at each phase of the study period, as indicated in Table 6. Calculations and results related to this work are presented in (Ebaid et al. 2013).

Taking well (W25) as a sample to calculate the additional PV panels' cost, including the $1 \%$ real interest rate (see section "Operation costs") would result in the following:

$$
\begin{aligned}
\mathrm{PV} \mathrm{\text {Cost } _ { \mathrm { Add } }}=\operatorname{Cost}_{\mathrm{PV}}\left[\begin{array}{c}
(\mathrm{PV})_{5 \text { years }}\left(\frac{P}{F}\right)(F, 1 \%, 5) \\
+(\mathrm{PV})_{10 \text { years }}\left(\frac{P}{F}\right)(F, 1 \%, 10)+ \\
(\mathrm{PV})_{15 \text { years }}\left(\frac{P}{F}\right)(F, 1 \%, 15) \\
+(\mathrm{PV})_{20 \text { years }}\left(\frac{P}{F}\right)(F, 1 \%, 20)
\end{array}\right] \\
=500[(182 \times 0.9515)+(127 \times 0.9053) \\
+(73 \times 0.8613)+(53 \times 0.8195)] \\
=\mathrm{US \$ 196,500}
\end{aligned}
$$

Table 6 Total number of PV panels required by each of the design wells at each pumping phase (Ebaid et al. 2013)

\begin{tabular}{lllll}
\hline Well number & W25 & W39 & W34 & W47 \\
\hline Initial (0-5 years) & 2969 & 3503 & 3847 & 3827 \\
Added (5-10 years) & 182 & 173 & 158 & 85 \\
Added (10-15 years) & 127 & 120 & 111 & 60 \\
Added (15-20 years) & 73 & 69 & 62 & 34 \\
Added (20-25 years) & 53 & 51 & 47 & 24 \\
Total & 3403 & 3916 & 4226 & 4031 \\
\hline
\end{tabular}

Regarding system batteries, additional quantities will also be needed as the power requirements increase. Battery age is usually determined by the number of the charge-discharge cycles or otherwise by years. Total number of added and replaced batteries needed during the project is divided into three categories (Ebaid et al. 2013).

1. Backup batteries which will also have to be replaced in the 15th year (note that it will not be so frequently charged and discharged, and its life could be extended).

2. Night-time operation batteries, which will need to be replaced periodically, depending on a life of 15 years. So replacement will occur at the 15 th year.

3. Supplementary batteries, to be added at the 5th, 10 th, 15th and 20th year.

The calculations of the number of replacement and addition batteries for each category listed in Table 7 can be found in Ebaid et al. (2013).

Table 8 lists the total present worth costs of additional PV components that will be required at each pumping phase of the 25 year operation period.

\section{Genset replacement and addition costs}

Although generators lifespan or maximum working hours depend on how well the engine is being maintained and the surrounding weather conditions, it is strongly recommended the genset be replaced after 10 years of continuous duty in harsh weather conditions, such as that of Disi, to ensure the reliability of the genset parts, Arif et al. (2010). Accordingly, for this alternative, the two gensets would probably need to be replaced by a brand new one every 10 years, which will result in an additional cost of US\$181,429 at the 10th year and US\$164,286 at the 20th year, totalling US\$354,714, all in present worth considering a real interest rate of $1 \%$.

\section{Electrical grid replacement and addition costs}

There are usually several upgrades for the electrical grid components along with other failure replacement occasions. Therefore, the replacement and addition 
Table 7 Batteries to be added and replaced at each design well and the corresponding years (Ebaid et al. 2013)

\begin{tabular}{|c|c|c|c|c|c|c|c|c|c|c|c|c|}
\hline \multirow{2}{*}{$\begin{array}{l}\text { Well } \\
\text { Year }\end{array}$} & \multicolumn{3}{|l|}{ W25 } & \multicolumn{3}{|l|}{ W39 } & \multicolumn{3}{|l|}{ W34 } & \multicolumn{3}{|l|}{ W47 } \\
\hline & Night & Backup & Supp. & Night & Backup & Supp. & Night & Backup & Supp. & Night & Backup & Supp. \\
\hline Fifth & - & - & 73 & - & - & 69 & - & - & 63 & - & - & 34 \\
\hline Tenth & - & - & 51 & - & - & 48 & - & - & 45 & - & - & 24 \\
\hline 15th & 539 & 539 & 29 & 700 & 700 & 27 & 769 & 769 & 25 & 745 & 745 & 14 \\
\hline 20th & - & - & 21 & - & - & 20 & - & - & 19 & - & - & 9 \\
\hline
\end{tabular}

costs (combined with repair and maintenance costs of Section "Electrical grid maintenance and repair costs" for the electrical grid alternative in this study can be assumed to equal $2.5 \%$ per year of the initial grid cost), according to the National Electric Power Company NEPCO Ltd., (International Monetary fund 2009). This equals US $\$ 4500$ /year per well or about US $\$ 100,000$ /year per well considering a $1 \%$ real interest rate.

\section{Residual value (salvage value)}

Residual value is the net worth of a system at the end of the LCCA operation period. This is the only cost category in an LCCA where a negative value, one that reduces cost, is acceptable.

\section{PV component residual value}

PV panels The PV system components are expected to return a salvage value through selling it at the end of the project to various types of recycling industries. According to experts, PV panel recycling is currently not viable because waste volumes generated are too small and significant volumes of end-of-life panels will only begin to appear in 2025 or 2030. Based on PV cycle's reported experiences in the 2010 collection and recycling activities, a price of 175 euros (almost was agreed on per ton of end-of-life silicon PV panels (Bio Intelligence Service et al. 2011). It should be noted that salvage logistics' costs can vary based on the collection and transport system chosen and the distance between the collection point and the recycling centre of PV panels. Referring to the mechanical data of the Canadian Solar MaxPower CS6X-300P panels, the weight of one panel is almost $27 \mathrm{~kg}$. And based on a price of US\$286/ton for the endlife PV panels, while considering a real interest rate of $1 \%$; the salvage value of end-of-life PV panels for each design well can be obtained through using Eq. 9:

$$
\begin{aligned}
\text { PV Cost } & \text { Salvage }= \\
& \times \text { Price US\$ } / \text { ton } \times P / F(F, n, i)
\end{aligned}
$$

Batteries Regarding the end-of-life (scrap) lead-acid batteries and based on the market, its usual price range is US\$0.4-1.5 $/ \mathrm{kg}$. This price depends on the condition of those batteries, if it is wet (contains acid) or dry,

\begin{tabular}{|c|c|c|c|c|c|c|c|c|c|}
\hline \multicolumn{2}{|l|}{ Well number } & \multicolumn{2}{|l|}{ W25 } & \multicolumn{2}{|l|}{ W39 } & \multicolumn{2}{|l|}{ W34 } & \multicolumn{2}{|l|}{ W47 } \\
\hline Period & Component & Quantity. & Cost (US\$) & Quantity & Cost (US\$) & Quantity & Cost (US\$) & Quantity & Cost (US\$) \\
\hline \multirow[t]{3}{*}{ Added and replaced fifth year } & PV panels & 182 & 87,143 & 173 & 82,857 & 158 & 75,714 & 85 & 40,000 \\
\hline & Batteries & 73 & 68,571 & 69 & 65,714 & 63 & 60,000 & 34 & 32,857 \\
\hline & Inverters & - & & - & & - & & - & \\
\hline \multirow[t]{3}{*}{ Added and replaced tenth year } & PV Panels & 127 & 57,143 & 120 & 54,286 & 111 & 50,000 & 60 & 27,143 \\
\hline & Batteries & 51 & 45,714 & 48 & 42,857 & 45 & 41,429 & 24 & 21,429 \\
\hline & Inverters & - & & - & & - & & - & \\
\hline \multirow[t]{3}{*}{ Added and replaced 15th year } & PV Panels & 73 & 31,429 & 69 & 30,000 & 62 & 27,143 & 34 & 14,286 \\
\hline & Batteries & 1107 & 952,857 & 1427 & $1,228,571$ & 1563 & $1,345,714$ & 1504 & $1,295,714$ \\
\hline & Inverters & 1 & 97,143 & 1 & 97,143 & 1 & 97,143 & 1 & 97,143 \\
\hline \multirow[t]{3}{*}{ Added and replaced 20th year } & PV Panels & 53 & 25,714 & 51 & 21,429 & 47 & 18,571 & 24 & 10,000 \\
\hline & Batteries & 21 & 17,143 & 20 & 17,143 & 19 & 15,714 & 9 & 7,143 \\
\hline & Inverters & - & 87,143 & - & 82,857 & - & - & - & - \\
\hline \multicolumn{2}{|c|}{ Total present worth (US\$) at $i_{r}=1 \%$} & $1,382,857$ & & $1,640,000$ & & $1,731,429$ & & $1,545,714$ & \\
\hline
\end{tabular}

Table 8 Addition and replacement cost of PV components for each design well at each pumping phase 
damaged or with a good container, and even sometimes the ampere-hour rating would be included in the pricing www.recycle.net. For this study, an average price of US\$1.1 $/ \mathrm{kg}$ for the wet-scrap lead-acid batteries will be selected after reviewing the local market prices. Therefore, Eq. 10 can be used to estimate the scrap battery salvage value and results depend on the total number of batteries to be used (as batteries will be replaced at the 15th year.

Referring to battery weight of $193 \mathrm{~kg}$ and using a real interest rate of $1 \%$ to bring costs back to present worth.

$$
\text { Battery } \text { Cost }_{\text {salvage }}=\sum \frac{\text { No. of Batteries } \times \text { Weight }(\mathrm{kg})}{(\text { Battery } \times \text { Price US } \$ / k g) \times P / F(F, n, i)}
$$

Other salvage values would be related to mounting materials for the PV system components, protection equipment, copper wires... etc. Its estimated costs can be assumed to equal $3 \%$ of the total salvage value of panels and batteries. Table 9 lists all the salvage values for PV system components

\section{Genset residual value}

The price of an end-of-life generator totally depends on its condition. But in all cases, it will not exceed 10-20\% of the initial cost referring to the local market trends. Therefore, in this study, the residual value of the genset is to be taken as $15 \%$ of the initial costs. That result in an estimated total present worth salvage value of US\$814,29 (as six generators will be bought throughout the study period, two will be sold at the 10th year, another two at the 20th year and the last two at the 25th year) using a real interest rate of $1 \%$.

\section{Electrical grid residual value}

The residual value of the electrical grid system can be discarded since it will not happen in practical life to dismantle the grid components and sell it to profit back money.

\section{Final life cycle cost analysis (LCCA)}

Once all pertinent costs have been established and discounted to their present value, the costs can be

Table 9 Estimated salvage values for PV system components

\begin{tabular}{lllll}
\hline Well number & W25 & W39 & W34 & W47 \\
\hline PV panels (US\$) & 22,857 & 27,143 & 30,000 & 30,000 \\
Batteries (US\$) & 317,143 & 374,286 & 411,429 & 398,571 \\
Other material (US\$) & 10,000 & 12,857 & 12,857 & 12,857 \\
Total present worth (US\$) & 350,000 & 414,286 & 454,286 & 441,429 \\
\hline
\end{tabular}

summed up to generate the total life cycle cost of the project alternative $\mathrm{LCC}_{\text {Alternative }}$ according to Eq. 11

$$
\begin{aligned}
\mathrm{LCC}_{\text {Alternative }}= & \text { Cost }_{\text {Initial }}+\text { Cost }_{\text {Operation }} \\
& + \text { Cost }_{\text {Maintenance }}+\text { Cost }_{\text {Add Replace }} \\
& - \text { Cost }_{\text {Residual }}(\mathrm{US} \$)
\end{aligned}
$$

It should be noted here Eq. 11 does not include the cost of $\mathrm{CO}_{2}$ emission reduction and the cost of selling of PV power during the project period because the evaluation methods and rules applied must be uniform. In our case, LCCA can provide quantitative results, thereby enabling comparison of each technology on an equal footing. The alternative cost per $\mathrm{kWh}\left(\operatorname{cost}_{\mathrm{kWh}}\right)$ is to be calculated through dividing the $\mathrm{LCC}_{\text {Alternative }}$ by the total useful energy $E_{\text {Useful }}$ in $\mathrm{kWh}$ over the study period, as indicated by Eq. 12:

$$
\text { Cost }_{\mathrm{kWh}}=\left(\frac{\mathrm{LCC}_{\text {alternative }}}{\mathrm{E}_{\text {Useful }}}\right)(\mathrm{CF}) \quad(\mathrm{US} \$ / \mathrm{kWh})
$$

where $\mathrm{CF}$ is the contingency factor to compensate for additional miscellaneous costs. In this study, $\mathrm{CF}=5 \%$ is assumed. To estimate $E_{\text {Useful }}$ of each design well, the integration of motor power $P_{m}$ over the operation period is performed. And since the operation period was divided into five phases, the total useful energy can be calculated through Eq. 13

$$
E_{\text {useful }}=\int_{0}^{25} f\left(P_{m}\right) d P_{m}
$$

The yearly power demand data are shown in Fig. 7 depends on what the total useful power demanded at each design well $E_{\text {Useful }}$ can be estimated to be equal $37.32 \times 10^{6}, 43.7 \times 10^{6}, 50.1 \times 10^{6}$ and $46.9 \times 10^{6} \mathrm{kWh}$ for wells W25, W39, W34 and W47, respectively, during the whole operation period of 25 years.

\section{Results}

\section{PV component final LCCA}

The total life cycle cost for the PV system alternative can be estimated through returning all costs in the PV cash flow diagram of Fig. 9 to present worth and applying Eqs. 11 and 12 for each design well to yield the results listed in Table 10. It should be noted here that including the cost of $\mathrm{CO}_{2}$ reduction in the final PV LCCA will lower the $\operatorname{Cost}_{\mathrm{PV}, \mathrm{kWh}}$ even further and eventually gives a great advantage of using renewable energy over conventional types of energy alternatives.

\section{Genset final LCCA}

Two Caterpillar 250-kW generators are to be used. According to Eq. 11, the LCCs for a 24-diesel genset 


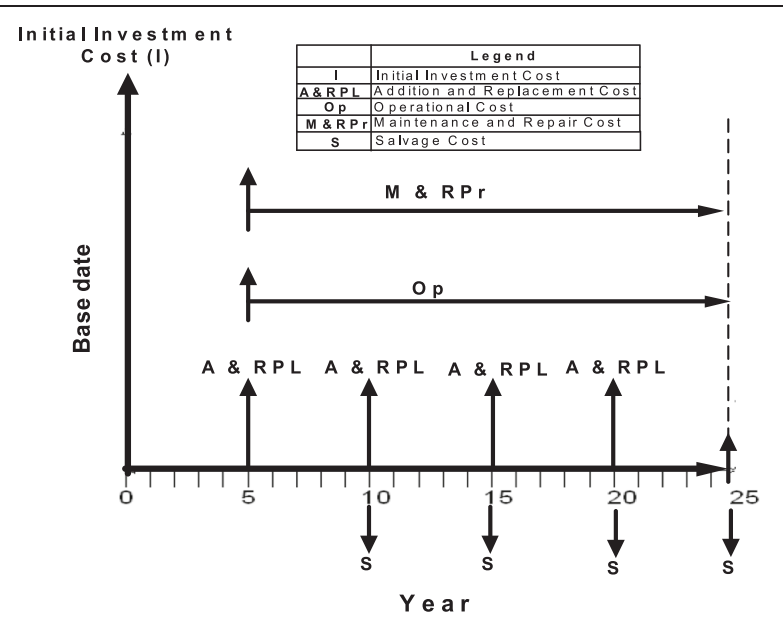

Fig. 9 Cash flow diagram for the PV alternative LCC

alternative at each design well are listed in Table 11, and Fig. 10 shows the cash flow diagram of genset LCCA.

\section{Electrical grid through Disi desert final LCCA}

The grid system alternative to supply Disi wells with electrical power varies considerably in LCC between design wells. This is due to varying initial costs according to the distance from the well to the nearest grid available. At the same time, operational costs depend on the amount of electrical power required by the well pump. Table 12 lists down the LCC values for each design well according to the electrical grid alternative, and Fig. 11 shows its cash flow diagram.

\section{PV-grid and PV-genset combinations final LCCA}

To investigate the effect of combining pairs of alternatives PV-genset and PV-electrical grid to create more

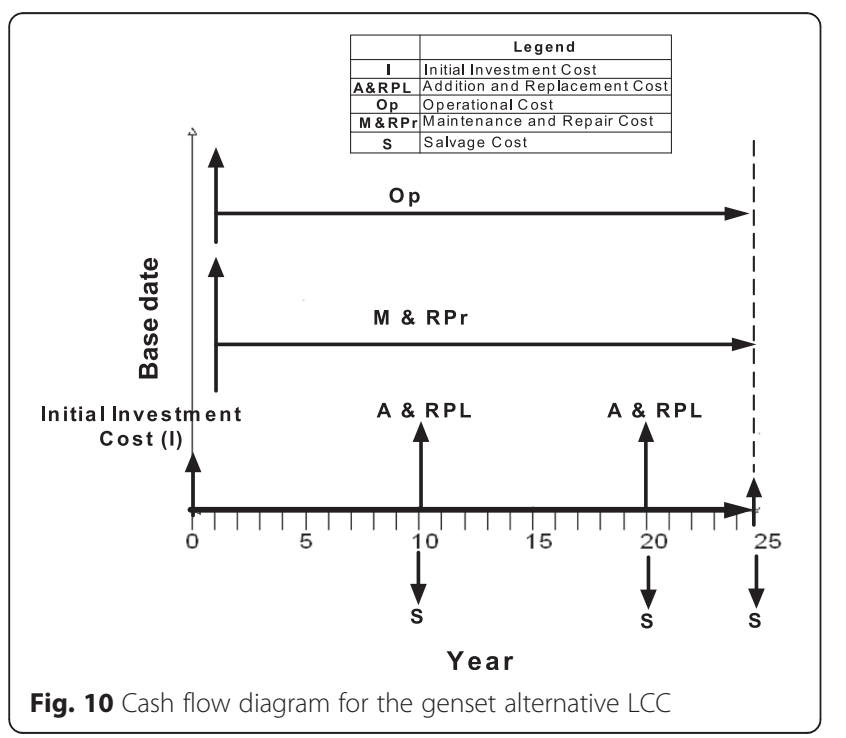

Table 10 Final PV LCCA and cost per kWh values of each design well in present worth (PW) (US\$)

\begin{tabular}{lllll}
\hline Costs (US\$) & W25 & W39 & W34 & W47 \\
\hline Cost $_{\text {Initial }}$ & $3,007,143$ & $3,528,571$ & $3,864,286$ & $3,844,286$ \\
Cost $_{\text {Operation }}$ & 204,286 & 234,286 & 252,857 & 241,429 \\
Cost $_{\text {Maintenance }}$ & 24,524 & 28,114 & 30,343 & 28,971 \\
Cost $_{\text {Add }} \&_{\text {Replace }}$ & $1,382,857$ & $1,640,000$ & $1,731,429$ & $1,545,714$ \\
Cost $_{\text {Residual }}$ & 350,000 & 414,286 & 454,286 & 441,429 \\
LCC $_{\text {PV }}($ US\$) & $4,968,810$ & $5,845,257$ & $6,333,201$ & $6,101,829$ \\
Cost $_{\text {PV }, \text { kWh }}($ US\$/KWh) & 0.139 & 0.140 & 0.126 & 0.137 \\
\hline
\end{tabular}

options for decision-makers, the following additional two options could be implemented:

- 12-h PV day operation, 12-h diesel genset night operation system.

- 12-h PV day operation, 12-h electrical grid night operation system.

From the first look, the PV-genset option seems to be more appealing than the PV grid option, since the construction of a grid system would necessarily weaken the chance for a feasible use of a PV array. On the other hand, the commonly used PV-genset option for off-grid systems would significantly decrease the initial costs of a night-operating PV system but would result in higher operational and fuel costs. Combining the individual cost banks, after splitting it into halves, since the options are for 50-50 operation, would result in the costs listed in Table 13. It can be noticed that combining a PV array system with a grid network would result in lower costs than that of a PV-genset network. That would be returned to the expensive diesel costs and high fuel consumption by the generator.

\section{Sensitivity analysis}

Sensitivity analysis is a technique for determining which input values, if different, would make a crucial difference to the outcome of the analysis.

Table 11 Final genset LCC and cost per kWh values of each design well in present worth (US\$)

\begin{tabular}{lllll}
\hline Costs (US\$) & W25 & W39 & W34 & W47 \\
\hline Cost Initial $_{\text {Cost }}$ & 200,000 & 200,000 & 200,000 & 200,000 \\
Cost $_{\text {Maintenance }}$ & $6,934,286$ & $8,855,714$ & $8,855,714$ & $9,357,143$ \\
Cost $_{\text {Add }} \&_{\text {Replace }}$ & 632,857 & 632,857 & 632,857 & 632,857 \\
Cost $_{\text {Residual }}$ & 345,714 & 345,714 & 345,714 & 345,714 \\
LCC $_{\text {Genset }}$ (US\$) & 81,429 & 81,429 & 81,429 & 81,429 \\
Cost $_{\text {GEnset,kWh }}$ (US\$/KWh) & 0.231 & 0.243 & 0.243 & 0.238 \\
\hline
\end{tabular}


Table 12 Final grid LCC and cost per kWh values of each design well in present worth (US\$)

\begin{tabular}{|c|c|c|c|c|}
\hline Costs (US\$) & W25 & W39 & W34 & W47 \\
\hline$\overline{\text { Cost }_{\text {Initial }}}$ & 180,000 & 180,000 & 180,000 & 180,000 \\
\hline Costoperation & $4,942,857$ & $5,742,857$ & $6,531,428$ & $6,071,428$ \\
\hline Cost $_{\text {Maintenance }}$ & 100,000 & 100,000 & 100,000 & 100,000 \\
\hline \multicolumn{5}{|l|}{ Cost $_{\text {Add }} \&_{\text {Replace }}$} \\
\hline Cost $_{\text {Residual }}$ & 0 & 0 & 0 & 0 \\
\hline LCC Grid $_{\text {GS\$) }}$ & $5,222,857$ & $6,022,857$ & $6,811,429$ & $6,351,429$ \\
\hline Cost $_{\text {Grid,kWh }}($ US\$/KWh) & 0.147 & 0.145 & 0.143 & 0.142 \\
\hline
\end{tabular}

\section{Sensitivity analysis of PV system}

(Table 10, shows that addition and replacement cost, operation cost, and residual cost constitute the input critical parameters of the LCC whereas the maintenance cost has much smaller effect on LCC). In this case, it may be advisable to spend additional time and money on determining the degree of uncertainty associated with the annual costs of add and replacement and operation cost. There is usually somewhat less uncertainty with the initial investment cost because it occurs at or close to the base date.

\section{Sensitivity analysis of genset system}

Table 11, shows that the input critical parameters to the LCC are operation cost, addition and replacement cost, and maintenance cost whereas residual cost has much smaller effect on LCC. Explanation of these costs are similar to the costs of PV system case.

\section{Sensitivity analysis of grid system}

From Table 11, the critical inputs which affect the LCC outcomes are only the operation cost. Other costs have minor effect on the LLC analysis.

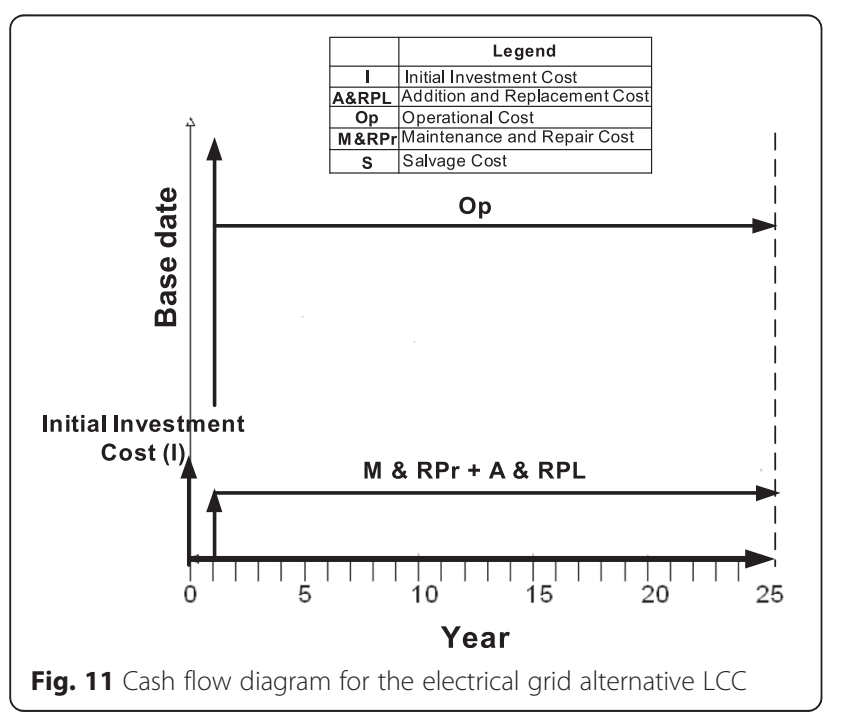

Table 13 Well-averaged final LCC and cost per kWh for combined alternatives

\begin{tabular}{lll}
\hline Costs (US\$) & 12-h PV, 12-h genset & 12-h PV, 12-h grid \\
\hline Cost $_{\text {Iitial }}$ & $1,880,536$ & $1,870,000$ \\
Cost $_{\text {Operation }}$ & $4,429,643$ & $3,027,143$ \\
Cost $_{\text {Maintenance }}$ & 330,357 & 38,571 \\
Cost $_{\text {Add }} \&_{\text {Replace }}$ & 960,357 & 812,857 \\
Cost $_{\text {Residual }}$ & 247,857 & 207,143 \\
LCC & $7,848,750$ & $5,955,714$ \\
Cost $_{\text {kWh }}$ (US\$/KWh) & 0.185 & 0.140 \\
\hline
\end{tabular}

Final averaged LCCA summary for power alternatives Summarizing the final results of the average life cycle cost analysis of each alternative in ascending order, Table 14 combines those results to simplify comparison. It clearly shows that the PV system alternative has the least cost for all design wells (which applies for all wells in the Disi wellfield) and is the most feasible.

\section{Payback period}

Payback period (PBP) can be defined as follows:

$$
\mathrm{PBP}=\frac{\text { Initial investment }}{\text { Annual saving }}
$$

\section{Payback period for the PV system}

The initial investment is based on the average PV component costs of the four wells and equal to US\$3,504,791 (see Table 4), and the annual saving is based on the average motor pump $P_{m}$ of the four selected well and equal 190.018 kW (see Fig. 5).

$$
\begin{aligned}
\text { PV energy generated yearly } & =190.018 \times 24 \times 365 \\
& =1,664,558 \mathrm{kWh}
\end{aligned}
$$

Assuming an average cost of $0.4 \mathrm{US} \$ / \mathrm{kWh}$, then

Annual saving $=1,664,558 \times \mathrm{US} \$ 0.4=\mathrm{US} \$ 665,823$

Table 14 Final average LCCA Summary

\begin{tabular}{lll}
\hline Power alternative & $\begin{array}{l}\text { Average LCC } \\
\text { (US\$/25 years) }\end{array}$ & $\begin{array}{l}\text { Average cost per kWh } \\
\text { (US\$/kWh) }\end{array}$ \\
\hline PV & $5,812,274$ & 0.135 \\
PV/grid & $5,955,714$ & 0.140 \\
Grid & $6,102,143$ & 0.144 \\
PV-genset & $7,848,750$ & 0.185 \\
Genset & $9,720,000$ & 0.239 \\
\hline
\end{tabular}




$$
\mathrm{PBP}=\frac{\text { Initial investment }}{\text { Annual saving }}=\frac{3,504,791}{665,523}=5.25 \text { years }
$$

\section{Payback period for the genset system}

The initial investment of gensets = US\$200,000

The Annual Saving = Annual Saving (kWh/year) Generated - (Diesel cost + Maintenance cost).

Energy generated yearly by genset

$$
\begin{aligned}
& =(1,664,558 \mathrm{kWh} / \text { year }) \times 3600 \\
& =5,992,248,800 \mathrm{~kJ}
\end{aligned}
$$

Amount of diesel consumed yearly

$$
\begin{aligned}
& =\frac{\text { Energy generated }}{\text { Heating value }}=\frac{5,992,248,800}{44,000} \\
& =136,187 \mathrm{~kg}=170,234 \mathrm{~L}
\end{aligned}
$$

Assuming an average cost of US $\$ 3 / \mathrm{kWh}$, then

Diesel cost yearly $=170,234 L \times \mathrm{US} \$ 3 / L$

$$
=\mathrm{US} \$ 510,702
$$

Yearly Maintenance cost $=\frac{590,948}{25}=\mathrm{US} \$ 23,637 \quad$ (see Table 5)

Then, the PBP can be calculated as

$$
\begin{aligned}
\mathrm{PBP}=\frac{\text { Initial investment }}{\text { Annual saving }} & =\frac{200,000}{(665,523)-(510,702+23,637)} \\
& =1.5 \text { years }
\end{aligned}
$$

\section{Payback period for the 12-h PV day operation, 12-h grid at night combination}

If the PV system is working for $12 \mathrm{~h}$, then the annual saving yearly is equal to

$$
\begin{gathered}
\text { PV Energy generated yearly }=190.018 \times 12 \times 365 \\
=832,279 \mathrm{kWh}
\end{gathered}
$$

\section{Payback period for the 12-h PV day operation, 12-h genset at night combination}

$$
\begin{aligned}
\text { Energy generated yearly by genset }= & (832,279 \mathrm{kWh} / \text { year }) \\
& \times 3600 \\
= & 2,996,204,400 \mathrm{~kJ} / \text { year }
\end{aligned}
$$

Amount of diesel consumed yearly

$$
\begin{aligned}
& =\frac{\text { Energy generated }}{\text { Heating value }}=\frac{2,996,204,400}{44,000} \\
& =68,096 \mathrm{~kg}=85,119 \mathrm{~L}
\end{aligned}
$$

Diesel cost yearly $=85,119 \mathrm{~L} \times \mathrm{US} \$ 3 / \mathrm{L}=\mathrm{US} \$ 255,358$

$$
\begin{aligned}
\mathrm{PBP}=\frac{\text { Initial investment }}{\text { Annual saving }} & =\frac{200,000}{(665,523)-(255,358+23,637)} \\
& =3 \text { years }
\end{aligned}
$$

\section{Environmental survey and risk assessment}

During normal operation, PV power systems do not emit substances that may threaten human health or the environment. In fact, through the savings in conventional electricity production, it can lead to significant emission reductions. There are, however, several indirect environmental impacts and risk aspects related to PV power systems that require further consideration.

\section{$\mathrm{PV}$ and $\mathrm{CO}_{2}$ emission reduction in Jordan}

Electricity in Jordan is being produced through the conventional fuel combustion (oil and natural gas), which is continuously emitting greenhouse gases. Referring to the International Energy Agency IEA report about the $\mathrm{CO}_{2}$ emission from fuel combustion, the energy supply to Jordan in 2009 reached $312 \times 10^{15} \mathrm{~J}$. This energy emitted a total of 19.2 million tons of $\mathrm{CO}_{2}$ (almost 61.6 tons of $\mathrm{CO}_{2}$ per $\left.10^{12} \mathrm{~J}\right)$. At the same time, while the 2009 power output for electricity and heat in Jordan was almost $14.3 \times$ $10^{9} \mathrm{kWh}, 8.3$ million tons of $\mathrm{CO}_{2}$ were accordingly emitted, with an emission rate of $581 \mathrm{gm} \mathrm{CO}_{2} / \mathrm{kWh}$. That exceeded the $500 \mathrm{gm} \mathrm{CO}_{2} / \mathrm{kWh}$ world average of that year. The average emission in Jordan was $642 \mathrm{gm} \mathrm{CO}_{2}$ / kWh through 2002-2009. By taking the total energy demand of each design well, Fig. 12 summarizes the $\mathrm{CO}_{2}$ emission that could have been produced using the conventional fuel-combustion power systems, which, through using the PV energy, will all be eliminated.

The elimination of indicated $\mathrm{CO}_{2}$ emissions, which could reach an average of 27,172 tons per well during the operation period and sum up to almost 1.5 million tons for all 55 wells, has a huge positive influence on the environment. The reduction of environmental costs by reducing contamination has many aspects to be discussed, and it eventually gives a great advantage of using renewable energy over conventional types of energy.

\section{PV environmental challenges}

The production of present-generation PV power systems is relatively energy intensive, involves the use of large 

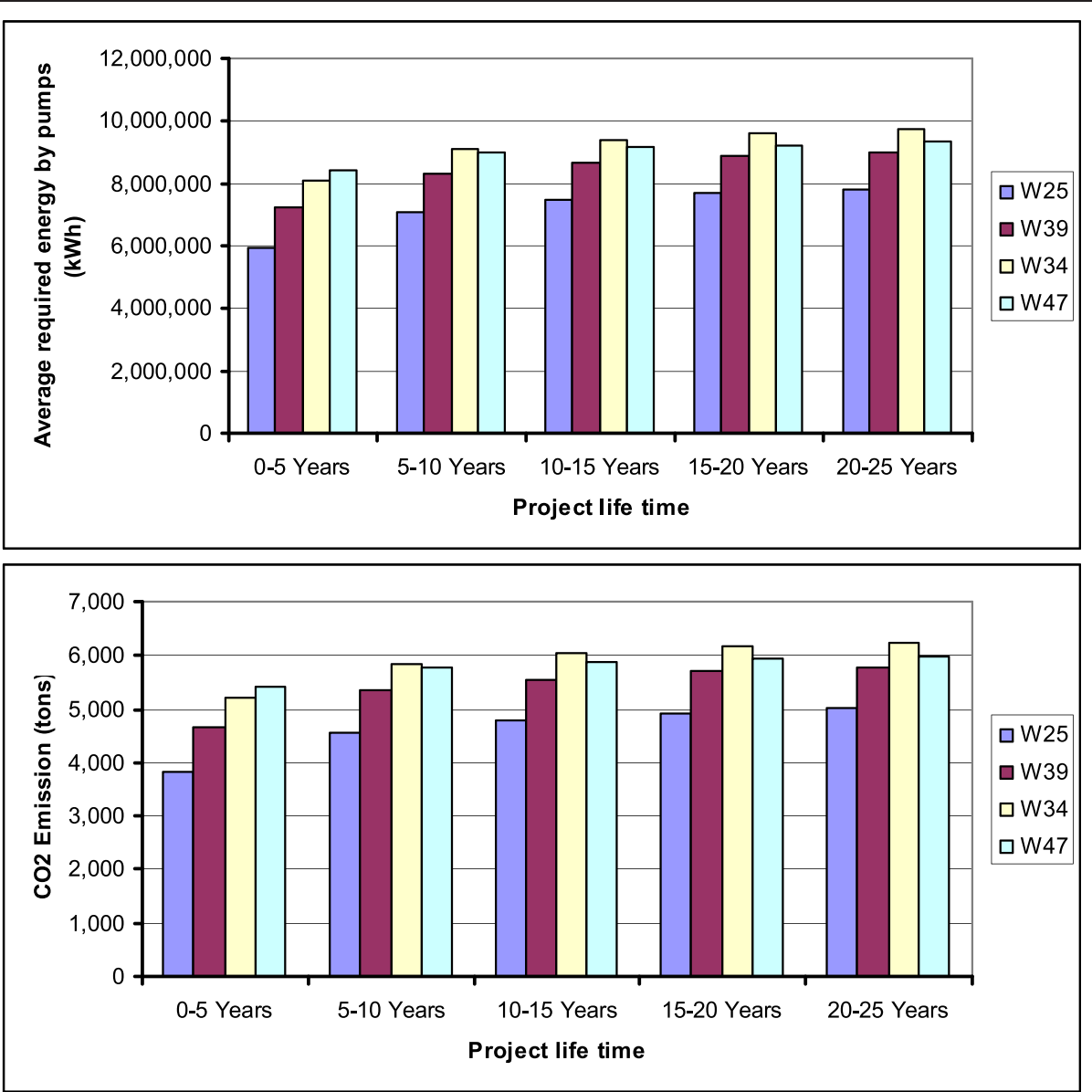

Fig 12 Possible emission of $\mathrm{CO}_{2}$ due to use of conventional energy of each design well for an average required energy demand by the pumps in $\mathrm{kWh}$ (emitted $\mathrm{CO}_{2}$ in tons (using a rate $642 \mathrm{gm} \mathrm{CO} / \mathrm{kWh}$ ))

\section{Energy Pay Back Time (yr) of present PV systems}

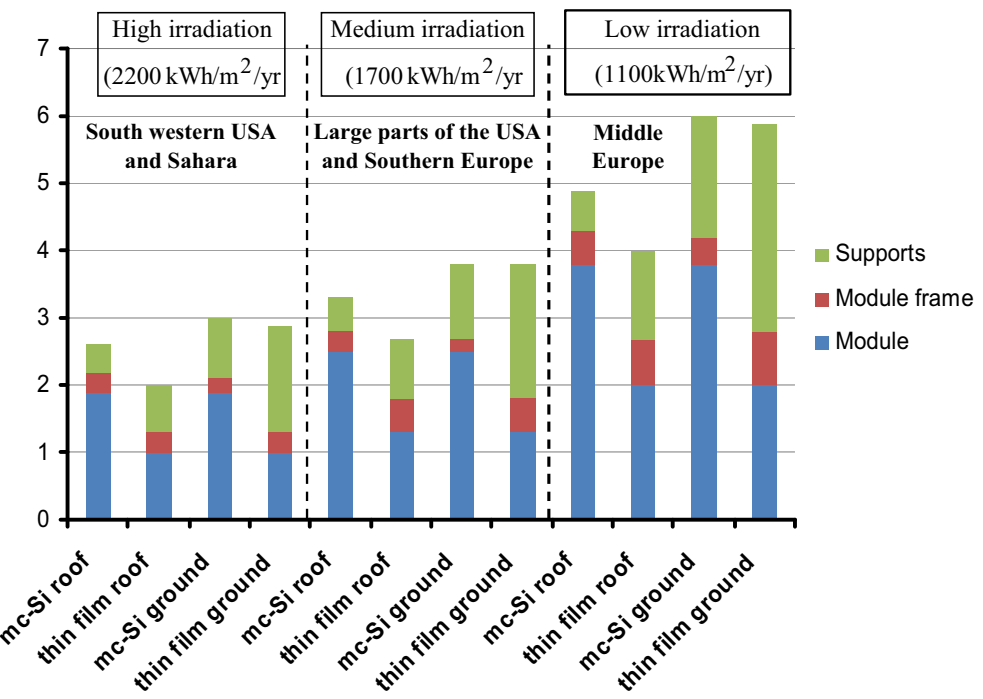

Fig. 13 The energy pay-back time (in years) for present-day PV applications (Alsema and Nieuwlaar 2000) 
Table 15 Energy consumption and $\mathrm{CO}_{2}$ emission for PV module production

\begin{tabular}{|c|c|c|c|c|c|}
\hline \multirow[t]{3}{*}{ PV Type } & \multirow{3}{*}{$\begin{array}{l}\mathrm{CO}_{2} \text { emission for } \mathrm{PV} \\
\text { production }\left(\mathrm{Kg} \mathrm{CO} / \mathrm{CO}_{2}\right)\end{array}$} & \multicolumn{4}{|c|}{ Total tons of $\mathrm{CO}_{2}$ emission for each well } \\
\hline & & W25 & W39 & W34 & W47 \\
\hline & & 3403 panels $(1021$ kWp $)$ & 3916 panels $(1175 \mathrm{~kW})$ & 4226 panels $(1268 \mathrm{~kW})$ & 4031 panels $(1209$ kW $)$ \\
\hline Mono-crystalline & 360 & 368.0 & 423.0 & 356.0 & 435.0 \\
\hline Poly-crystalline & 170 & 174.0 & 200.0 & 217.0 & 206.0 \\
\hline
\end{tabular}

Source: Krauter and Ruther (2003)

quantities of bulk materials and smaller quantities of substances that are scarce and/or toxic. During operation, damaged modules or a fire may lead to the release of environmentally hazardous substances. Finally, at the end of their useful lifetime, PV power systems have to be decommissioned, and resulting waste have to be managed.

Although PV power systems do not require finite energy resources (as it is the case for fossil and nuclear systems) during their operation, a considerable amount of energy is needed at present for their production. Alsema and Nieuwlaar (Alsema and Nieuwlaar 1997) stated that energy payback time (EPBT) depends on several factors including cell technology, PV system application, location and irradiation. Further studies (Alsema and Nieuwlaar 2000) showed that the EPBT for presentday systems is 2 to 3 years in a sunny climate and increases to 4 to 6 years (or more) under less favourable conditions as shown in Fig. 13. Also note that the contribution from the supports and the module frames is significant, especially for the ground mounted systems.

The amount of energy in $\mathrm{kWh}$ required for the manufacturing of each $\mathrm{kW}_{\mathrm{p}}$ of PV panels (poly-crystalline-silicon selected for this project) and the corresponding emission of $\mathrm{CO}_{2}$ are listed in Table 15 based on studies conducted in the developing countries (Krauter and Ruther 2003). The total $\mathrm{CO}_{2}$ emission related to the number of PV panels to be used in for the W25 (see Table 6) can be calculated for mono and poly-crystalline as follows:

$$
\begin{aligned}
\text { Emission of }\left(\mathrm{CO}_{2}\right)_{\mathrm{W} 25}= & \left(\text { No. of PV panel } \times \mathrm{kW}_{\mathrm{P}}\right) \\
& \left.\times \frac{\left(\mathrm{CO}_{2}\right) \mathrm{kg}}{\mathrm{kW}_{\mathrm{P}} \times 1000} \text { (tons }\right)
\end{aligned}
$$

Mono-crystalline: $\quad \mathrm{CO}_{2}$ emission $=\left(\mathrm{CO}_{2}\right)_{\mathrm{W} 25}=\left(3403 \times \frac{300}{1000}\right) \times$ $\left(\frac{360}{1000}\right)=368.0$ (tons)

Poly-crystalline: $\mathrm{CO}_{2}$ emission $=\left(\mathrm{CO}_{2}\right)_{\mathrm{W} 25}=\left(3403 \times \frac{300}{1000}\right) \times$ $\left(\frac{170}{1000}\right)=174.0$ (tons)

Similar calculation for wells W39, W34 and W47 are carried out, and the results are listed in Table 15.

Note that these emission values are very tiny compared to those produced by fossil fuel combustion. However, the grid system components will also consume a considerable amount of energy for its production. In fact, the manufacturing of cement, steel, copper, insulation materials and the other grid components can cause a much larger amount of $\mathrm{CO}_{2}$ into the atmosphere, (Krauter and Ruther 2003). However, several other environmental challenges can be associated with the use of PV system

\begin{tabular}{|c|c|}
\hline & Description \\
\hline Hazard no. 1 & Electric shock may cause personnel injury to installers, occupants or others (would include local Disi animals and birds) \\
\hline Risk level & Negligible risk region \\
\hline Risk reduction & $\begin{array}{l}\text { Installation of a well-engineered system and understanding of potential hazard by design team, installation crew and } \\
\text { system user. And installation of complete set warning signs where applicable inside and around the PV system }\end{array}$ \\
\hline Hazard no. 2 & $\begin{array}{l}\text { Initiation of contact fire due to increased temperature of Disi area or the possibility of ray reflection from flat surfaces } \\
\text { on flammable objects }\end{array}$ \\
\hline Risk level & Tolerable risk region \\
\hline Risk reduction & $\begin{array}{l}\text { Insulate structure with fire proofing materials and implement a fire safety procedure, along with continuous check for } \\
\text { flammable objects that might be available }\end{array}$ \\
\hline Hazard no. 3 & Theft of PV equipment \\
\hline Risk level & Tolerable risk region \\
\hline Risk reduction & Hour-round surveillance on the PV plant through either physical present of personnel or computerized systems \\
\hline Hazard no. 4 & Communication Interference (e.g. inverters) \\
\hline Risk level & Tolerable risk region \\
\hline Risk reduction & Appropriate design and system installation based on good engineering practice must be adopted \\
\hline
\end{tabular}

Table 16 PV hazards 


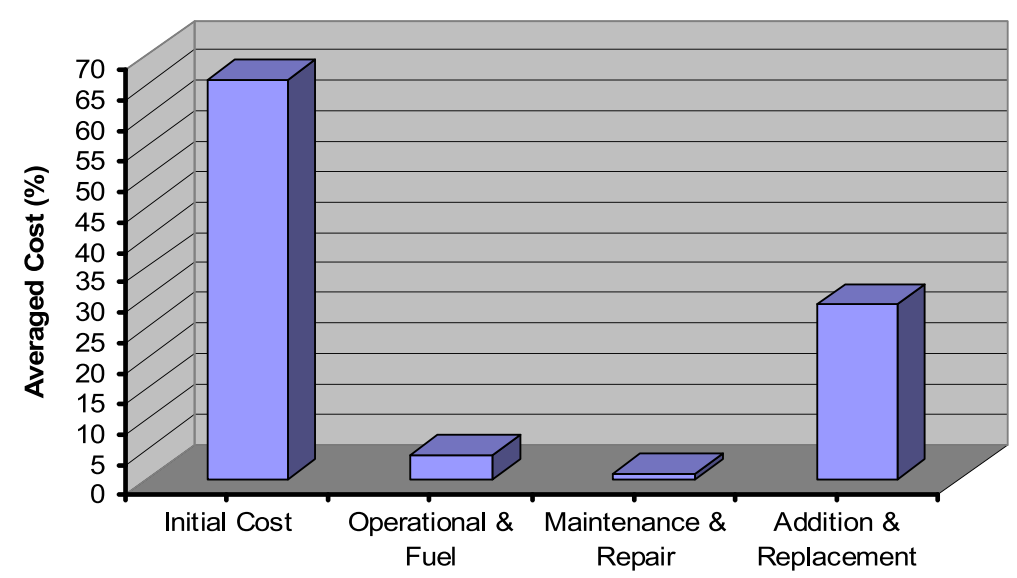

Fig. 14 PV alternative life cycle cost banks (averaged for all design wells)

components, mainly PV panels and batteries. The main environmental problems related to photovoltaic panels, if not properly disposed, are as follows: leaching of lead, leaching of cadmium, loss of conventional resources (primarily aluminum and glass) and loss of rare metals (silver, indium, gallium and germanium). These issues require more intense care during the recycling and disposal of PV system components. At the same time, rare metal recovery and component recycling is very essential for the durability of such materials in the natural cycle. The land required by PV arrays may sometimes take over natural life, through tree cutting or even soil desertification, and then the environmental aspects of this issue would have to be considered. In the case of this study, the available land is almost barren and lacks any form of natural life expect for some desert plants. Therefore, the effect on natural life can almost be discarded.

\section{Risk assessment}

Risk assessment is the process of evaluating risks to workers' safety and health from workplace hazards. It is a systematic examination of all aspects of work that considers the following:

- What could cause injury or harm,

- Whether the hazards could be eliminated and, if not,

- What preventive or protective measures are, or should be, in place to control the risks.

Several types of minor hazards can be related to a PV plant; these hazards can be easily controlled and reduced through identifying them, and then preparing a suitable plan for safety procedures to avoid risk. Some PV hazards may be described as shown in Table 16. However, that for each hazard identified, action plan should be prepared and implemented to minimize accidents during the lifetime of the project.

\section{Discussion}

Life cycle cost analysis (LCCA)

The use of a $1 \%$ real interest rate depended on an optimistic consideration of the inflation rate history in Jordan.

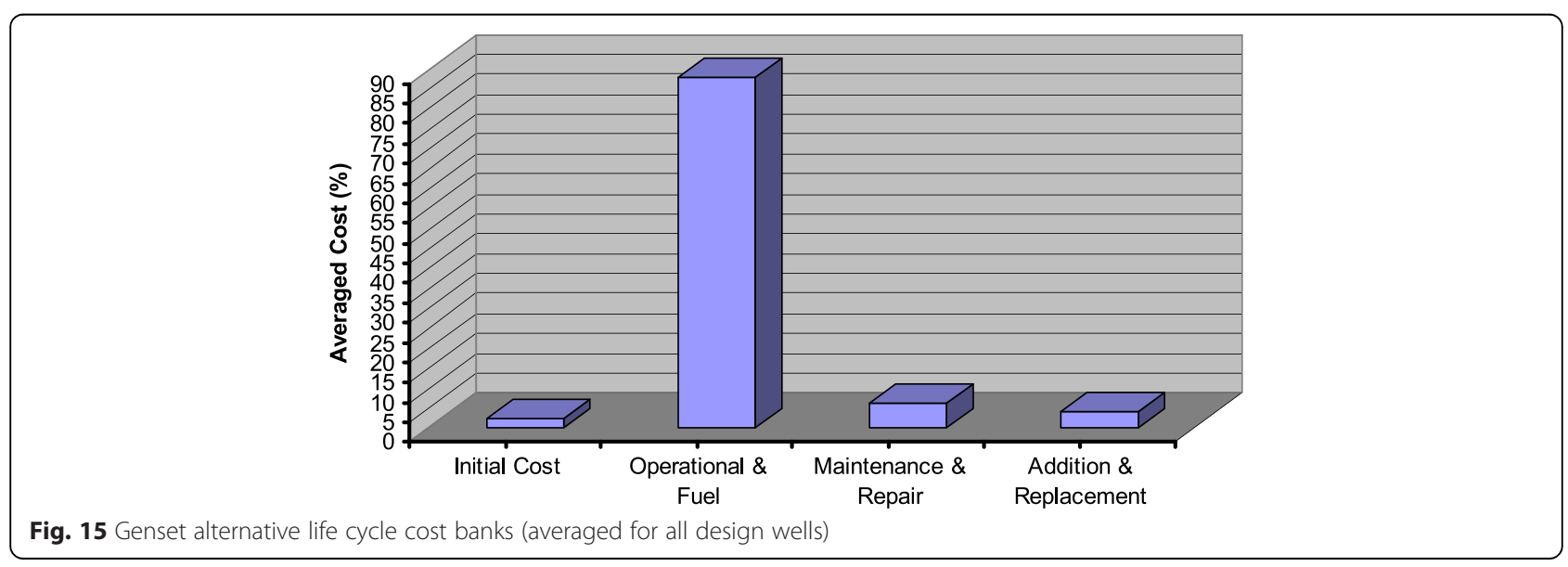




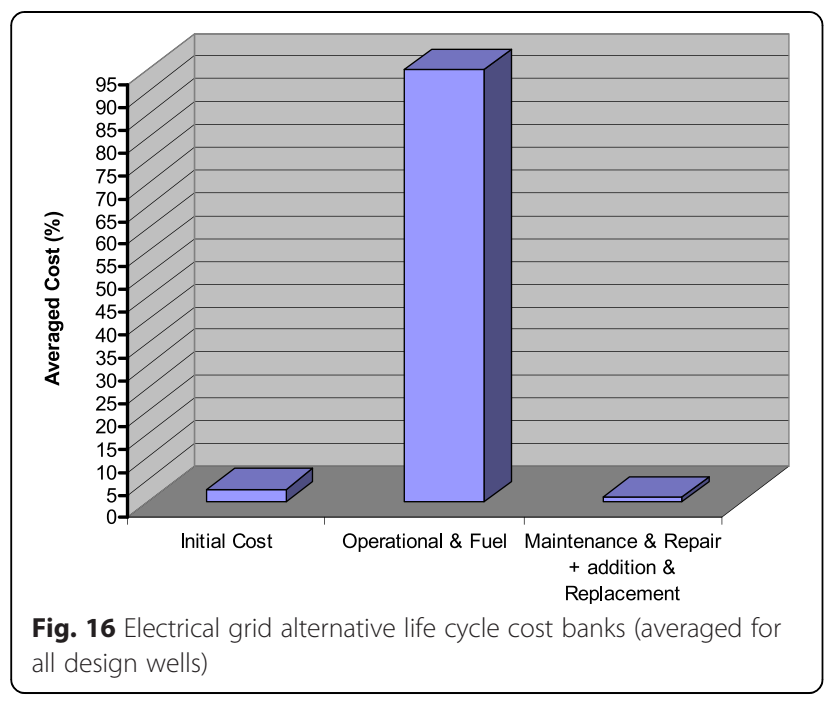

More conservative prediction of real interest rates would be preferable, but in the case of this study, the effect of low interest rate can be normalized since it was applied evenly to all alternatives. Looking at the well-averaged cost banks for each alternative, as illustrated in Figs. 14, 15 and 16, it can be noticed that the operational and fuel costs are the major cost banks for the genset and grid alternatives, contributing in 88 and $95 \%$ of its total costs, respectively. While for the PV alternative, the operational cost (e.g. no fuel cost) only represents $4 \%$. On the other hand, initial costs contribution in the total cost represents $66 \%$ for the PV alternative, where it only equals $2 \%$ for the genset and $3 \%$ for the grid.

Based on these observations, it can be concluded that operational costs for PV systems are very minimal and can almost be discarded. On the other hand, the continuous research in the field of renewable energy, along

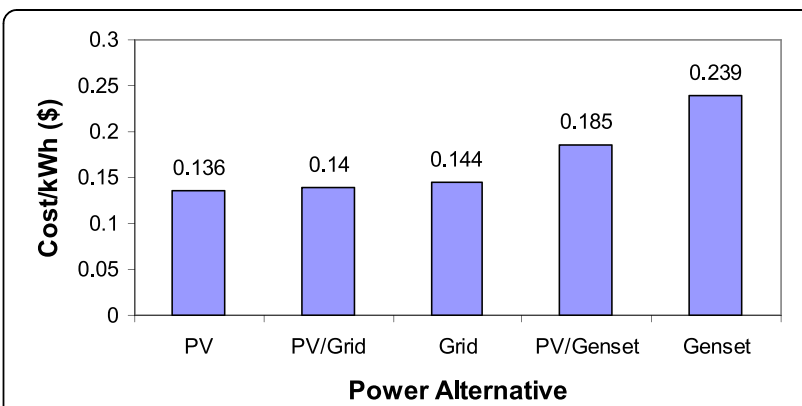

Fig. 18 Cost/kWh for all alternatives (averaged for all design wells)

with commercial competitiveness among PV component manufacturers, would only help in decreasing the high implementation costs of those components, which will result in significantly reducing the total PV energy costs. As per the steep increase of fuel prices and electricity tariffs due to the economical situation worldwide, the total life cycle costs of genset and grid electricity will increase more in the future. Accordingly, the conventional energy costs will continue to rapidly increase,

Figure 17 compares each cost bank among all alternatives. It demonstrates that the initial cost of the PV system, even if considered relatively high, is still much smaller than operational and fuel costs of the grid or the genset alternatives.

It can be noticed that combining a PV array system with a grid network would result in lower costs than that of a PVgenset network. That would be returned to the expensive diesel costs and high fuel consumption by the generator.

\section{Conclusions}

A complete economic analysis for the Disi project of 13-MW power output was conducted for all five powering options. These are grid, genset, PV, PV-grid

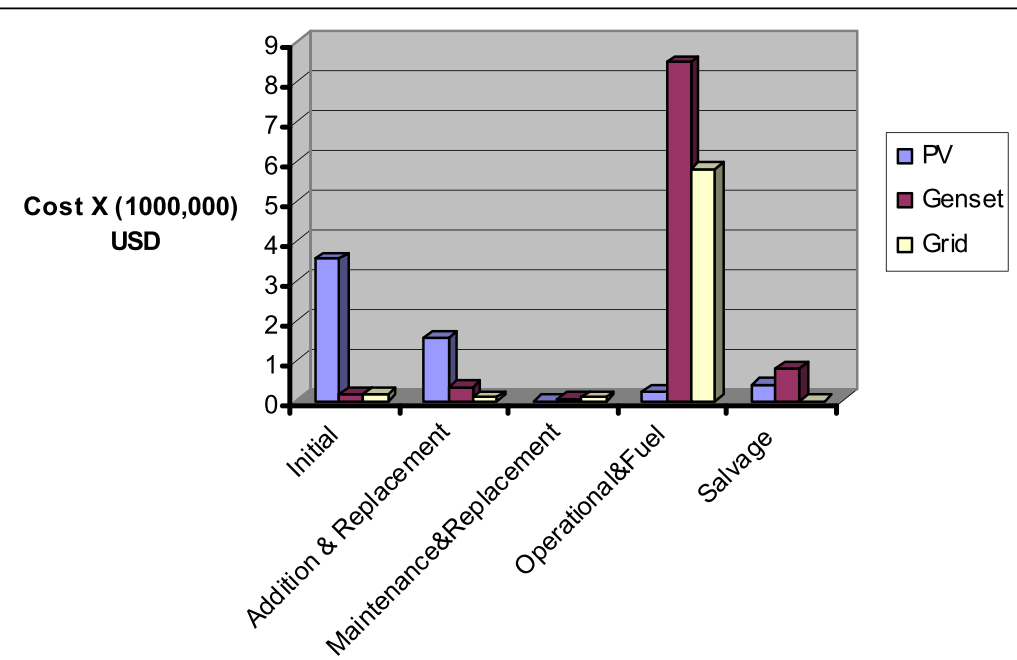

Fig. 17 All alternatives life cycle cost banks (averaged for all design wells) 
and PV-genset and the method used was based on the life cycle cost method (LCC). Comparison of the cost per $\mathrm{kWh}$ for all five powering options is illustrated in Fig. 18. It clearly shows that the order of best-to-worst alternative from an economical point of view would be the 24-h PV system, the PV-grid option, the grid option, the PV-genset, and finally the worst option is using a diesel generator for 24-h operation.

It can be noticed that the operational and fuel costs are the major cost banks for the genset and grid alternatives, contributing in 88 and $95 \%$ of its total costs consecutively, respectively. While for the PV alternative, it only represents $4 \%$. On the other hand, initial costs contribution in the total cost represents $66 \%$ for the PV alternative, where it only equals $2 \%$ for the genset and $3 \%$ for the grid. Based on these observations, it can be concluded that operational costs for PV systems are very minimal and can almost be discarded.

As we project into the future, the price of PV is surely to come down while the price of oil is likely to go up. This can lead to a reduction in the years to break even. It has also been proved that PV systems are an environment friendly source of energy, in which, the resulting savings in $\mathrm{CO}_{2}$ emission reached 30,000 tons per well throughout the study period ( 25 years), which summed up to about 1.5 million tons of $\mathrm{CO}_{2}$ for all Disi wells.

\section{Nomenclature}

$A$ present value of an annuity

$A_{\mathrm{DC}}$ direct current

CF contingency factor

$D_{i}$ inner diameter of a pipe $(\mathrm{m})$

DD drawdown (m)

Wp watt peak

$E_{\text {Useful }}$ total useful energy (kJ)

$H_{L}$ head loss (m)

$i$ normal interest rate (\%)

$i_{r}$ real interest rate $(\%)$

$i_{f}$ inflation rate (\%)

$i_{\text {eff }}$ effective real interest rate

$f$ friction factor

$n$ total life (years)

$P W$ present worth value of money

$P$ present value

$P_{m}$ motor power $(\mathrm{kW})$

$P_{p}$ pump power

$P_{w}$ water power

$\dot{Q}$ volume flow rate $\left(\mathrm{m}^{3} / \mathrm{s}\right)$

SWL static water level (m)

THP total pump head

$V$ velocity of water $(\mathrm{m} / \mathrm{s})$

$\eta_{P}$ pump efficiency (\%)

$\eta_{m}$ motor efficiency (\%)

\section{Abbreviations}

A\& RPL: addition and replacement cost; Ah: ampere hour; CAT: Caterpillar; $\mathrm{CO}_{2}$ : carbon dioxide; $\mathrm{DD}$ : drawdowns; F: future; FL: friction loss; I: initial cost; IEA: international energy agency; IMF: international monetary fund; JEPCO: Jordanian Electric Power Company; LCC: life cost cycle; LCCA: life cycle cost analysis; M \& RPr: maintenance and repair cost; NEPCO: National Electric Power Company; NIST: National Institute of Standards and Technology; Op: operational cost; PV: photovoltaic; S: salvage cost;

Supp: supplementary; W: well.

\section{Competing interests}

The authors declare that they have no competing interests.

\section{Authors' contributions}

$\mathrm{MH}$ carried out the economic analysis and participated in the discussion of the results. ME carried out the sensitivity analysis and the study of the design and selection of the wells. both authors contributed to the environmental analysis and risk assessment. Also, both authors read and approved the final manuscript.

\section{Author details}

'University of Jordan, Amman, Jordan. ${ }^{2}$ Philadelphia University Jordan, Amman, Jordan.

Received: 3 December 2014 Accepted: 29 May 2015

Published online: 28 July 2015

\section{References}

Abu-Aligah, M (2011). Design of photovoltaic water pumping system and compare it with diesel powered pump. Jordan Journal of Mechanical and Industrial Engineering (JJMIE), 5, 273-280.

Alsema, E, \& Nieuwlaar, E (1997). Environmental aspects of PV power systems. Report, Netherlands: IEA PVPS Task Workshop.

Alsema, E, \& Nieuwlaar, E (2000). Energy viability of photovoltaic systems. Energy Policy, 28, 999-1010

Arif, A, Bilton, A, Dubowsky, S, Wiesman, R, \& Zubair, S (2010). On the feasibility of community-scale photovoltaic-powered reverse osmosis desalination systems for remote locations. KSA: Massachusetts Institute of Technology and King Fahd University of Petroleum and Minerals Paper.

Bio Intelligence Service (2011), Study of photovoltaic panels supplementing the impact assessment for a recast of the WEEE directive. European Commission, Report, France. http://ec.europa.eu/environment/waste/weee/pdf/ Study\%20on\%20PVs\%20Bio\%20final.pdf. Accessed date 20, march, 2011

Blignaut, J, Heerden, J, \& Jordan, A (2005). On the inflationary effects of higher electricity prices in South Africa. Paper, South Africa: National Electricity Regulator (NER).

Caterpillar C9 250kW genset, USA, http://www.wpowerproducts.com/DieselGenerators-1-c-8.html (last, accessed 18, Dec., 2012).

Chandrasekar, B, \& Kandpal, TC (2005). Effect of financial and fiscal incentives on the effective capital cost of solar energy technologies to the user. Solar Energy, 78(147-56), 2005.

Ebaid, MSY, Qandil, H, \& Hammad, H (2013). A Unified approach for designing a photovoltaic solar system for the underground water pumping well-34 at Disi aquifer. Energy Conversion and Management, 75, 780-795.

Elker, B (2005). Solar powered water pumping systems. Trakia Journal of Sciences, $3,7-11$.

Ellington J, Abadesco E (2015) The Disi-Amman water conveyance project. Courses.Washinton.edu/ceJordan/Disipresentation.pdf. Accessed 8 May 2015.

Firatoglu, Z, \& Yesilata, B (2004). New approaches on the optimization of directed coupled PV pumping systems. Solar Energy, 77, 81-93.

Fisher, I (1977). The theory of interest. Philadelphia: Porcupine Press. ISBN 0-87991-864-0.

GAMA Enerji Co. Disi project technical report, Jordan, 2010. Accessed 11-2011.

Goodrich, A, James, T, \& Woodhouse, M. (2011). Solar PV manufacturing cost model group: installed solar PV system prices. Report, USA: National Renewable Energy Laboratory (NREL).

Grima, Z (2015). Techno-economic analysis of photovoltaic pumping system for rural water supply in Ethiopia. International Journal of Sustainable Energy. doi:10.1080/14786451.2015.1017498.

Hansen, T, Moore, L, Mysak, T, \& Post, H (2005). Photovoltaic power plant experience at Tucson Electric Power. USA: Tucson Electric Power Company and Sandia National Laboratories Paper. 
Heath, R (1983) Basic ground water hydrology. USA Geological Survey Water Supply Paper 2220 Textbook. http://pubs.er.usgs.gov/pubs/wsp/wsp2220. Accessed P:03, 2014.

Helikson, HJ, Haman, DZ, Baird, CD, (1991) Pumping water for irrigation using solar energy. University of Florida, Florida cooperation extension services, Institute of Food and Agriculture Sciences, Fact sheet EES-63, November 1991

Recycler's World, Exchange rate for recycling lead acid batteries. http:// www.recycle.net/battery/index.html, Last accessed 20-02-2014.

International Energy Agency (IEA) (2011), $\mathrm{CO}_{2}$ emissions from fuel combustion-highlights. Report. IEA, USA

International Energy Agency (IEA) (2009), Technology roadmap-solar photovoltaic energy. Report. IEA. USA.

International Monetary fund (2009) Jordan: article IV consultation-staff report; public information notice on the executive board discussion and statement by the executive director for Jordan. IMF Country Report No. 09/159. May 2009.

International Monetary fund (2010) Jordan: article IV consultation-staff report; public information notice on the executive board discussion and statement by the executive director for Jordan. IMF Country Report No. 10/18, 2010.

Kolhe, M, and Kolhe, S, Joshi J, (2002) Economic viability of stand-alone solar photovoltaic system in comparison with diesel-powered system for India, India Energy Economics, 3, 2002

Kordab, M (2007). Priority option of photovoltaic systems for water pumping in rural areas in ESCWA member countries. Lebanon: United Nations Economic and Social Commission for Western Asia (ESCWA) Workshop.

Krauter, S, \& Ruther, R (2003). Considerations for the calculation of greenhouse gas reduction by photovoltaic solar energy. Journal of Renewable Energy, 29, 345-355.

Mahjoubi, A, Mechlouch, R, Ben Brahim, A, (2010) Economic viability of photovoltaic water pumping systems in the desert of Tunisia, Proceedings of International Renewable Energy Congress, Soussa, Tunisia, 5-7, Nov. 2010.

Mahjoubi A. Mechlouch RF, Belgacem (2013) Techno-economic analysis and modelling of a remote photovoltaic water pumping system in the desert of Tunisia. International Journal of Sustainable Energy, vol. 32, 334-448, 2013

Mahmouda, E, \& Natherb, H (2003). Renewable energy and sustainable developments in Egypt: photovoltaic water pumping in remote areas. Applied Energy, 74, 141-47.

National Electric Power Company of Jordan NEPCO, Annual report, 2011. www.nepco.com.jo/store/docs/web/2011_en.pdf. accessed Jan. 2010.

Odeh, I, Yohanis, YG, \& Norton, B (2006). Economic viability of photovoltaic water pumping systems. Journal of Solar Energy, 80, 850-860.

Parajuli, R, Pokharel, GR, \& Alberg, P (2104). A comparison of diesel, biodiesel and solar PV-based water pumping systems in the context of rural Nepal. International Journal of Sustainable Energy, 33, 536-553.

Purohit, P (2007). Financial evaluation of renewable energy technologies for irrigation water pumping in India. Energy Policy, 35, 3134-44.

Qoaider, L, \& Steinbrecht, D (2010). Photovoltaic systems: a cost competitive option to supply energy to off-grid agricultural communities in arid regions. Applied Energy, 87, 427-435.

Roy, RB (2012). Design and performance analysis of the solar PV DC water pumping system. Canadian Journal on Electrical and Electronics Engineering, 3(403-412), 2012.

Sahin, A, \& Rehman, S (2012). Economical feasibility of utilizing photovoltaics for water pumping in Saudi Arabia. International Journal of Photoenergy, 2012, 9

Senol, R (2012). An analysis of solar energy and irrigation systems in Turkey. Energy Policy, 47, 478-486.

Short, T, \& Oldach, R (2003). Solar powered water pumps: the past, the present and the future. J Solar Energy Eng, 125, 76-82.

Tamrat, B (2007). Comparative analysis of feasibility of solar PV, wind and micro hydro power generation for rural electrification in the selected sites of Ethiopia. Thesis, Ethiopia: Addis Ababa University.

Thomas, MG (1993). "Water pumping: the solar alternative. Albuquerque, NM: SAND8T-0804, Sandia National Laboratories photovoltaic Systems Design Center.

van der Zwaan, B (2003). Prospects of for PV: a learning analysis curve. Solar energy, 74, 19-31.

\section{Submit your manuscript to a SpringerOpen ${ }^{\circ}$ journal and benefit from:}

- Convenient online submission

- Rigorous peer review

- Immediate publication on acceptance

- Open access: articles freely available online

- High visibility within the field

- Retaining the copyright to your article

Submit your next manuscript at $>$ springeropen.com 